\title{
Cell-Type-Specific Role of $\Delta$ FosB in Nucleus Accumbens In Modulating Intermale Aggression
}

\author{
- Hossein Aleyasin, ${ }^{1}$ @Meghan E. Flanigan, ${ }^{1}$ @Sam A. Golden, ${ }^{2}$ @Aki Takahashi, ${ }^{1,3}$ @Caroline Menard, ${ }^{1,4}$ \\ Madeline L. Pfau, ${ }^{1}$ Jacob Multer, ${ }^{1}$ - Jacqueline Pina, ${ }^{1}$-Kathryn A. McCabe, ${ }^{5}$ Naemal Bhatti, ${ }^{1}$ Georgia E. Hodes, ${ }^{6}$ \\ Mitra Heshmati, ${ }^{1}$ Rachael L. Neve, ${ }^{7}$ @Eric J. Nestler, ${ }^{1}$ @Elizabeth A. Heller, ${ }^{8}$ and ${ }^{\circledR S}$ Scott J. Russo ${ }^{1}$ \\ ${ }^{1}$ Fishberg Department of Neuroscience, Friedman Brain Institute, and Center for Affective Neuroscience, Icahn School of Medicine at Mount Sinai, New \\ York, New York 10029, ${ }^{2}$ Neurobiology of Relapse Section, Intramural Research Program, National Institute on Drug Abuse-National Institutes of Health, \\ Baltimore, Maryland 21224, ${ }^{3}$ Laboratory of Behavioral Neuroendocrinology, University of Tsukuba, Tsukuba, Ibaraki, 305-8577, Japan, ${ }^{4}$ Département de \\ psychiatrie et neuroscience, Faculté de médecine and CERVO Brain Research, Université Laval, Quebec City, Quebec G1V 0A6, Canada, ${ }^{5}$ Marymount \\ Manhattan College, New York, New York 10021, ${ }^{6}$ Virginia Polytechnic Institute and State University, Blacksburg, Virginia $24061,{ }^{7}$ Gene Delivery \\ Technology Core, Harvard University and Massachusetts General Hospital, Cambridge, Massachusetts 02139, and ${ }^{8}$ Department of Systems Pharmacology \\ and Translational Therapeutics, Perelman School of Medicine, University of Pennsylvania, Philadelphia, Pennsylvania 19104
}

A growing number of studies implicate the brain's reward circuitry in aggressive behavior. However, the cellular and molecular mechanisms within brain reward regions that modulate the intensity of aggression as well as motivation for it have been underexplored. Here, we investigate the cell-type-specific influence of $\Delta \mathrm{FosB}$, a transcription factor known to regulate a range of reward and motivated behaviors, acting in the nucleus accumbens (NAc), a key reward region, in male aggression in mice. We show that $\Delta$ FosB is specifically increased in dopamine D1 receptor (Drd1)-expressing medium spiny neurons (D1-MSNs) in NAc after repeated aggressive encounters. Viral-mediated induction of $\Delta$ FosB selectively in D1-MSNs of NAc intensifies aggressive behavior without affecting the preference for the aggression-paired context in a conditioned place preference (CPP) assay. In contrast, $\Delta$ FosB induction selectively in D2-MSNs reduces the time spent exploring the aggression-paired context during CPP without affecting the intensity of aggression per se. These data strongly support a dissociable cell-type-specific role for $\Delta \mathrm{FosB}$ in the NAc in modulating aggression and aggression reward.

Key words: $\Delta$ FosB; aggression; cell-type specific; motivation; nucleus accumbens

Significance Statement

Aggressive behavior is associated with several neuropsychiatric disorders and can be disruptive for affected individuals as well as their victims. Studies have shown a positive reinforcement mechanism underlying aggressive behavior that shares many common features with drug addiction. Here, we explore the cell-type-specific role of the addiction-associated transcription factor $\Delta$ FosB in the nucleus accumbens in aggression. We found that $\Delta$ FosB expression promotes aggressive behavior, effects that are dissociable from its effects on aggression reward. This finding is a significant first step in identifying therapeutic targets for the reduction of aggressive behavior across a range of neuropsychiatric illnesses.

\section{Introduction}

Aggression is an innate social behavior that helps individuals to defend territory against competitors and increases the probability

Received Jan. 30, 2018; revised May 14, 2018; accepted May 20, 2018.

Author contributions: H.A. wrote the first draft of the paper; M.E.F., S.A.G., A.T., C.M., M.L.P., G.E.H., M.H., R.L.N., E.J.N., E.A.H., and S.J.R. edited the paper; H.A., M.E.F., S.A.G., A.T., E.A.H., and S.J.R. designed research;H.A., M.E.F., S.A.G., A.T., C.M., M.L.P., J.M., J.P., N.B., K.A.M., G.E.H., and M.H. performed research; R.L.N. and E.J.N. contributed unpublished reagents/analytic tools; H.A., M.E.F., S.A.G., J.M., J.P., N.B., and K.A.M. analyzed data; H.A. and S.J.R. wrote the paper.

This research was supported by the National Institutes of Health (Grants R01 MH114882, R01 MH104559, R01 MH090264, R37 DA007359, P50 MH096890, and P50 AT008661 to S.J.R.; Grants T32 MH087004, T32 MH096678, of successful mating (Lindenfors and Tullberg, 2011). Increasing evidence suggests that aggressive behavior is rewarding for dominant males and females across a range of species (Meisel and Joppa, 1994; Martínez et al., 1995; Farrell and Wilczynski, 2006; and F31 MH105217 to M.L.P.; Grant T32 MH096678 to M.F.); and Grant F30 MH100835 to M.H.). We thank Ashley Lepak, Lucy Bicks, and Jonathan Tai for technical assistance.

The authors declare no competing financial interests.

Correspondence should be addressed to Scott J. Russo, Fishberg Department of Neuroscience, Friedman Brain Institute, and Center for Affective Neuroscience, Icahn School of Medicine at Mount Sinai, 1425 Madison Ave., New York, NY 10029. E-mail: scott.russo@mssm.edu.

DOI:10.1523/JNEUROSCI.0296-18.2018

Copyright $\odot 2018$ the authors $\quad 0270-6474 / 18 / 385913-12 \$ 15.00 / 0$ 
Falkner et al., 2016). Recent studies implicate brain reward structures such as the nucleus accumbens (NAc) in mediating the motivational and rewarding aspects of aggressive behavior in mice (Couppis and Kennedy, 2008; Beiderbeck et al., 2012; Nehrenberg et al., 2013; Golden et al., 2016). It is possible that the rewarding nature of aggression can in some cases result in excessive aggression with potentially devastating consequences on society (Elbert et al., 2018).

To study aggressive behavior in mice, we adapted a resident intruder (RI) test that is a part of standardized social defeat model (Miczek and O'Donnell, 1978; Kudryavtseva et al., 1991; Berton et al., 2006; Golden et al., 2011). Using this procedure, we phenotyped mature, sexually experienced male CD-1 mice based on their behavior during an encounter with a mature but sexually naive C57BL/6J male intruder. Our previous findings showed that the majority of CD-1 males displayed aggressive behavior in response to an intruder male in their home cages. Only approximately one-third of the population did not display aggressive behavior toward the intruder and remained nonaggressive throughout the length of the social encounter. We showed further that aggressors (AGG) exhibit a conditioned place preference (CPP) toward the context where they encountered and had the opportunity to fight a submissive male mouse over the context where they did not have any social encounter (Golden et al., 2016). These data indicate that aggression is rewarding in a subset of male mice. Conversely, nonaggressor mice (NON) do not exhibit aggression toward the intruder and develop a conditioned place aversion (CPA) for the intruder-paired side of the CPP apparatus. Furthermore, aggressive mice lever press for access to submissive intruders, suggesting that mice are highly motivated to carry out aggressive behaviors (Golden et al., 2017a). These studies suggest addiction-like properties of aggressive behavior that might share underlying molecular mechanisms with drug addiction.

$\Delta$ FosB is a truncated splice product of the Fos $B$ gene that lacks the $\mathrm{C}$-terminal domains responsible in part for its rapid protein degradation (Carle et al., 2007). $\Delta$ FosB has a longer half-life than the full-length FosB protein and accumulates in the NAc due to chronic exposure to drugs, alcohol, exercise, sex and repeated stress (Robison and Nestler, 2011; Nestler, 2015). Research during the past two decades has defined a key role for $\Delta$ FosB in brain plasticity that facilitates reward/reinforcement and prosocial behaviors (Olausson et al., 2006; Wallace et al., 2008; Vialou et al., 2010; Nestler, 2012). Therefore, we hypothesized that $\Delta \mathrm{FosB}$, proposed as a molecular switch for addiction and mediator of behavioral resilience in stress conditions, may play a role in aggressive behavior and valence of aggressive encounters. Here, we show that $\Delta$ FosB is increased in dopamine D1 receptor (Drd1)-expressing medium spiny neurons (D1-MSNs), but not D2-MSNs, of the NAc in aggressive mice relative to nonaggressive mice. The functional effects of $\Delta$ FosB on aggressive behavior are cell-type specific, with $\Delta$ FosB in D1-MSNs promoting aggression but not aggression reward, whereas overexpression of $\Delta$ FosB in D2-MSNs, which is not natively elevated in these cells, has no effect on aggression but reduces aggression reward. These findings inform a greater understanding of the molecular basis of aggressive behavior, pointing to a dissociable role for $\Delta$ FosB in mediating aggression and aggression reward, and highlight a potential therapeutic strategy for treatment of maladaptive aggressive behavior.

\section{Materials and Methods}

Animals. Sexually mature and experienced CD-1 male mice were obtained from Charles River Laboratories (CRL) at 4-6 months of age $(35-45 \mathrm{~g})$. A history of equal access to females and successful breeding was confirmed by CRL. During transportation and arrival and throughout the experimentation period, $\mathrm{CD}-1$ male mice were singly housed. We used 7- to 8-week-old sexually naive C57BL/6J male mice $(20-25 \mathrm{~g})$ (IMSR catalog \#JAX:000664, RRID:IMSR_JAX:000664) and 6- to 8-weekold sexually naive BALB/cByJ (15-20 g) mice (IMSR catalog \#JAX:001026, RRID:IMSR_JAX:001026) supplied by The Jackson Laboratory as intruders. C57BL/6J and BALB/cByJ mice were group housed with males from the same strain throughout transportation and during the experimentation periods.

Transgenic male mice, D1-tdTomato mice (IMSR catalog \#JAX:016204, RRID:IMSR_JAX:016204), D1-Cre (MGI ID: 3836633), and D2-Cre mice (MGI ID: 3836635) used in this study were 12-16 weeks old (25-30 g) and had been backcrossed to wild-type C57BL/6J for $>11$ generations. To obtain sexual experience, they were paired with 8- to 12-week-old females, 3 weeks before the experiment and single housed throughout the experimentation period. Hybrid lines were generated by crossing transgenic D1-Cre or D2-Cre male mice of C57BL/6J background with CD-1 females. The first-generation progeny (F1) that carry the Cre-recombinase transgene were used. F1-hybrid mice used in this study were 3-4 months old $(35-45 \mathrm{~g})$ and paired with female mice of the same age for a 3 -week period before screening for aggression. They were then single housed through the experimentation period. All transgenic lines were bred in the animal facility at Icahn School of Medicine at Mount Sinai and genotyped by Transnetyx automated genotyping services.

All mice were maintained on a $12 \mathrm{~h}$ light/dark cycle with ad libitum access to food and water. Mice obtained from external suppliers were allowed 1 week to habituate in our facility before the start of each experiment. Breeding and procedures were performed in accordance with the National Institutes of Health Guide for Care and Use of Laboratory Animals and the Icahn School of Medicine at Mount Sinai Institutional Animal Care and Use Committee.

RI test. We performed the RI test to screen mice initially for their aggressive behavior. RI was performed according to our previously published work (Golden et al., 2011, 2016). Briefly, for CD-1 mice that were obtained from Charles River Laboratories, each resident mouse was exposed to a novel intruder (C57BL/6J) in its home cage for a period of 3 min daily for $3 \mathrm{~d}$. Interactions were recorded under standard indoor fluorescent lighting using a color digital camera located perpendicular to the cage. During RI sessions, the cage tops were replaced with a clear Plexiglas cover to allow unobstructed viewing and video recording. Recorded videos were analyzed and scored by a blinded observer to evaluate the following: (1) latency to initiate aggression also termed "attack latency," (2) the number of aggression bouts shown in figures as "\# attack bouts," (3) total duration of aggression per RI session termed "attack duration," (4) average duration of aggression per bout calculated as total duration of aggression divided by the number of aggression bouts termed as "attack duration per bout," and (5) social exploration behavior including sniffing, grooming, and nonaggressive social investigation. In this study, attack latency is defined as the time from the beginning of the RI session until the moment when the resident mouse initiated the first bite. In all screenings, attack latency was used as an indication of baseline aggression and to counterbalance the experimental cohorts before the viral injection. Each attack bout was defined by initiation of aggression with continuous orientation of the resident mouse toward the intruder. Each attack bout was considered complete when the resident mouse physically reoriented away from the intruder. Brief breaks shorter than $3 \mathrm{~s}$ were considered part of a continuous attack bout. Resident mice were defined as AGG if they initiated aggression every day during the $3 \mathrm{~d}$ of RI screening. NON mice did not display any aggressive behavior during any RI session. RI sessions were halted and the intruder was removed whenever the intruder showed any sign of physical injury or aggression toward the resident mouse during the interaction. The results of RI sessions are reported as the average of the $3 \mathrm{~d}$ of testing. 
To study cell-type-specific effects, we used 12- to 16-week-old D1tdTomato and D1-Cre and D2-Cre transgenic male mice (25-30 g) on a C57BL/6J background (see above). Because the C57BL/6J background strongly reduces aggression in these mice (Golden et al., 2017b), we exposed them to a $5 \mathrm{~min}$ instigation phase involving sensory exposure to a submissive male BALB/cBYj intruder through a perforated divider. After the instigation phase, the same BALB/cBYj mice were used for screening. The perforated divider was removed, allowing physical interaction between the resident and intruder mouse for $3 \mathrm{~min}$. To accommodate for the weak aggressive behavior in D1-Cre and D2-Cre transgenic mice on the C57BL/6J background, we considered the third day RI scores only for behavioral analysis within and between the groups.

To study the effects of cell-type-specific expression of $\Delta$ FosB on aggression $\mathrm{CPP}$, we generated hybrid lines by crossing a transgenic D1-Cre or D2-Cre male mouse of C57BL/6J background with a CD-1 female. We used the first generation progeny (F1-hybrid) that carried the Crerecombinase transgene. Because this F1 generation exhibits levels of aggression similar to CD-1 mice from Charles River Laboratories, they were screened similarly to CD-1 mice using a novel C57BL/6J mouse as an intruder (Golden et al., 2017b).

Aggression CPP. CPP experiments were performed as described previously (Golden et al., 2016, 2017b). Briefly, CPP was performed in three phases: pretest, acquisition, and test. All phases were performed and recorded under red light. In the pretest phase, mice were introduced to a CPP box consisting of two unique conditioning chambers connected by a neutral middle zone that allowed unbiased entry to either of the conditioning chambers. In the pretest phase, each mouse was allowed to roam freely between the chambers for $20 \mathrm{~min}$. On the following day, the acquisition phase commenced and was performed twice each day for $3 \mathrm{~d}$ in morning and afternoon sessions. During the acquisition phase, opaque plastic boards were inserted between conditioning chambers and the middle zone to confine mice to one of two chambers for $10 \mathrm{~min}$. During the morning sessions (between 9:00 and 11:00 A.M.), AGG mice were paired with submissive mice (C57BL/6J) in the assigned chamber. All morning sessions were recorded by a video camera to assess aggressive encounters. During afternoon sessions (between 2:00 and 4:00 P.M.), mice were confined to the opposite chamber without exposure to an intruder for $10 \mathrm{~min}$. On the test day all barriers were removed immediately after acquisition. Beginning in the morning (9:00 A.M.), mice were placed into the middle zone and allowed to roam freely in both chambers without intruders for $20 \mathrm{~min}$. Locomotor responses and time spent in each compartment were recorded and analyzed using EthoVision XT software (Noldus Information Technology, RRID:SCR_000441). We defined a CPP score for each animal as the time spent in the intruder-paired side minus the time spent in intruder-unpaired side during test and pretest. A positive score indicates an increase in preference and a negative score indicates a decrease in preference (aversion) to the intruder-paired side.

Social dominance (tube test). We performed the tube test on CD-1 AGG mice to determine social dominance during physical encounters between $\Delta$ FosB-overexpressing and control groups. To do this, we adapted the protocol used by Wang et al. (2011). Briefly, 5 weeks after virus injection, we repeated aggression screening to confirm the aggressive phenotype of all mice in each group. We then trained mice for $2 \mathrm{~d}$ before the test to habituate passing through one end of a 3 -cm-wide $\times 30$ - $\mathrm{cm}$-long clear plastic tube and exiting from the other side. This habituation phase ensured that all mice were able to comfortably pass through the narrow tube without resistance. The size of the tube is narrow enough that only one mouse can walk through it and cannot turn around or change direction. On the test day, mice were simultaneously placed at opposite ends of the tube. Mice were tested in a pairwise fashion with one control (AAVGFP) mouse against one $\Delta$ FosB-induced mouse (AAV- $\Delta$ FosB) using a round robin design for a total of three trials per mouse. The tube was cleaned between trials. Trials lasting $>120 \mathrm{~s}$ or those in which the mice did not meet in the center of the tube were discarded. The mouse that retreated with all four paws outside of the tube at the end of each trial was marked as the "loser." The "winner" was the mouse that forced its opponent to retreat. The percentage of trials won was used as a measure of social dominance.
Surgery and viral gene transfer. We performed all intra-NAc viral injections according to our previously published protocols under aseptic conditions using both local and general anesthesia (Christoffel et al., 2015; Golden et al., 2016; Heshmati et al., 2018). Briefly, mice were anesthetized with an intraperitoneal injection of a mixture of ketamine $(100 \mathrm{mg}$ per kg body weight) and xylazine (10 mg per kg body weight) supplemented by an intradermal injection of bupivacaine $(0.25 \%)$ into the scalp. We then positioned each mouse in a small-animal stereotaxic instrument (David Kopf Instruments) and the skull surface was exposed by a midline incision. Syringe needles ( $33 \mathrm{Ga}$; Hamilton) were used to infuse $0.5 \mu \mathrm{l}$ of virus bilaterally over a $5 \mathrm{~min}$ period. The needle was left in place for $5 \mathrm{~min}$ to allow for efficient diffusion before removal. NAc stereotaxic coordinates taken from bregma were as follows: anteroposterior +1.5 $\mathrm{mm}$; mediolateral, $+1.6 \mathrm{~mm}$; dorsoventral, $-4.4 \mathrm{~mm}$; at a $10^{\circ}$ angle. For non-conditioned $\Delta$ FosB expression, we used AAV2- $\Delta$ FosB-IRES-GFP $\left(1 \times 10^{12}\right.$ infectious unit/ml, UNC Vector Core $)$ and AAV2-hSyn-eYFP $\left(1.5 \times 10^{11-13}\right.$ infectious unit/ml, UNC Vector Core $)$ as a control. AAV injections were performed 4-6 weeks before behavioral experiments. For Fosb promoter suppression studies, we used a p1005 herpes simplex virus (HSV) vector expressing a 35-amino acid zinc-finger protein specifically designed to bind to the Fosb promoter fused with the catalytic moiety of G9a, a histone methyl transferase (HSV-Fosb-ZFP35-G9a) into the NAc. This Fosb-ZFP35-G9a construct represses the Fosb promoter by dimethylation of histone $\mathrm{H} 3$ at lysine 9 (H3K9me2) (Heller et al., 2014). A HSV expressing the zinc-finger but lacking G9a (HSV-FosbZFP35-NFD, no functional domain) was injected as a control. The p1005 vector is a dual promoter system in which an IE4/5 promoter drives a select gene of interest and a cytomegalovirus (CMV) promoter drives GFP expression as a marker of neuronal infection. Because repeated aggression increases the level of $\Delta$ FosB in the NAc, we waited $10 \mathrm{~d}$ after the last day of screening to inject the $\Delta$ FosB suppressing virus to allow for stabilization of $\Delta$ FosB to baseline levels. In addition, because HSV vectors reach their maximal expression level between 3 and $5 \mathrm{~d}$ postinjection [see (Neve et al., 2005)], we assessed the behavior of injected mice two days after the surgery by performing a 3-day home cage RI test (see Fig. $4 A$ ).

For cell type-specific expression of $\Delta$ FosB, we used HSV vectors encoding CMV-GFP or $\Delta$ FosB downstream of a stop codon flanked by loxP sites under the control of a IE4/5 promoter allowing expression of GFP in all transduced cells and expression of $\Delta \mathrm{FosB}$ only in cells expressing Cre-recombinase (HSV-LS1- $\Delta$ FosB) (Grueter et al., 2013). For all HSV studies, we performed behavioral assays from $24 \mathrm{~h}$ after injection of the viral vectors until day 5 after injection. The titer of all HSV vectors was $1 \times 10^{9}$ infectious units $/ \mathrm{ml}$.

Brain tissue preparation, immunostaining, and confocal microscopy. For histology and immunostaining, mice were given a euthanizing dose of $15 \%$ chloral hydrate and transcardially perfused with cold PBS, pH 7.4, followed by $4 \%$ paraformaldehyde. Intact brains were dissected out of the skull and incubated in cold $4 \%$ paraformaldehyde in PBS $\left(4-8^{\circ} \mathrm{C}\right)$ and postfixed for $18 \mathrm{~h}$. Brains were flash frozen after cryopreservation in 15\% and then $30 \%$ sucrose in PBS. To quantify cell-type-specific expression of $\Delta$ FosB, frozen brains were sliced in $25 \mu \mathrm{m}$ sections using a cryostat (Leica, CM1850). Sections were washed with PBS 3 times and incubated in blocking solution (3\% normal donkey serum, $0.3 \%$ Triton X-100 in PBS) for $2 \mathrm{~h}$. We then incubated them in primary antibody containing rabbit anti-FosB, 1:1000 (Santa Cruz Biotechnology catalog \#sc-48, RRID: AB_631515) and chicken anti-RFP, 1:200 (Rockland catalog \#600-901-379, RRID:AB_10704808) overnight at $4-8^{\circ} \mathrm{C}$. Slices were then washed in PBS 3 times for $10 \mathrm{~min}$ each, incubated in secondary antibody for $2 \mathrm{~h}$ in donkey anti-rabbit Cy2 1:400 (Jackson ImmunoResearch Laboratories catalog \#711-225-152, RRID:AB_2340612) and donkey anti-chicken Cy5 1:400 (Jackson ImmunoResearch Laboratories catalog \#703-175-155, RRID:AB_2340365) and washed in PBS for 30 min before staining with 1 $\mu \mathrm{g} / \mathrm{ml}$ DAPI (Sigma-Aldrich) for $20 \mathrm{~min}$ to stain nuclei. Sections were then mounted on microscopy slides, air-dried overnight, dehydrated, and coverslipped with DPX (Electron Microscopy Sciences). All slices were imaged using a Zeiss LSM 780 confocal microscope. For $\Delta$ FosB analysis, all images were taken at $40 \times$ magnification of the NAc from the rostral, middle and caudal regions $(\sim 1.70,1.18$, and $0.74 \mathrm{~mm}$ from the 
bregma, respectively) using the $z$-Stack function at $1 \mu \mathrm{m}$. Deconvolution was performed on all $z$-stacks with AutoQuant X (MediaCybernetics). Analysis of FosB-positive nuclei was performed using ImageJ (RRID: SCR_003070) to measure the intensity of signal in MSN nuclei (Matamales et al., 2009). Representative images were acquired at $10 \times$ magnification.

To assess placement and expression of viral vectors, coronal sections of the NAc ( +1.70 to $+0.38 \mathrm{~mm}$ from bregma) were prepared on a vibratome (Leica, VT $1000 \mathrm{~S}$ ) at $40 \mu \mathrm{m}$ and stored in PBS + sodium azide $\left(0.01 \% \mathrm{NaN}_{3}\right)$. After incubation in blocking solution (3\% normal donkey serum, $0.3 \%$ Triton X-100 in PBS), sections were incubated in primary antibody containing chicken anti-GFP 1:2000 (Aves Laboratories catalog \#GFP-1020, RRID:AB_10000240). Slices were then washed in PBS 3 times for 10 min each and incubated in secondary antibody containing donkey anti-chicken Cy2, 1:400 (Jackson ImmunoResearch Laboratories catalog \#703-225-155, RRID:AB_2340370) for $2 \mathrm{~h}$ and then washed in PBS for $30 \mathrm{~min}$ before staining with $1 \mu \mathrm{g} / \mathrm{ml}$ DAPI (SigmaAldrich) for $20 \mathrm{~min}$. Sections were then mounted on slides, air-dried, dehydrated, and coverslipped as described above. For representative images demonstrating the areas of viral infection, images were acquired with a Zeiss LSM 780 confocal microscope with a $10 \times$ objective and the tile-scan function. We used a $40 \times$ oil objective and snap shot function for detailed images. Expression and placement of viral injection site were plotted on schematic diagrams that represent front and back of the NAc ( $\sim 1.70$, and $0.74 \mathrm{~mm}$ from the bregma). Wrong placement, spreading of expression outside of the NAc, no detectable expression, and serious tissue damage were used as post hoc exclusion criteria for the experimental groups.

Bilateral NAc punches for RNA and protein. For RNA and protein extraction, mice were decapitated with a guillotine and brains were rapidly removed and placed in ice-cold PBS. Brains were placed on a cold mouse brain matrix (Zivic Instruments) and 1-mm-thick coronal slices were prepared. We used a core punch sampler (Harris, Uni-core, $2.0 \mathrm{~mm}$ ) to harvest bilateral NAc tissue on both sides (shown in Fig. 1). Core tissue samples were placed immediately on dry ice and stored at $-80^{\circ} \mathrm{C}$ until RNA or protein extraction.

Western blotting. Frozen NAc tissue samples were homogenized in 30 $\mu \mathrm{l}$ of RIPA buffer containing $10 \mathrm{~mm}$ Tris, $150 \mathrm{~mm} \mathrm{NaCl}, 1 \mathrm{~mm}$ EDTA, $0.1 \%$ SDS, $1 \%$ Triton X-100, and $1 \%$ sodium deoxycholate (Boston Bioproducts) supplemented with protease inhibitors (Sigma-Aldrich) using an ultrasonic processor. Protein concentrations were determined using a DC protein assay (Bio-Rad) and $50 \mu \mathrm{g}$ of protein was loaded onto $4-15 \%$ gradient Tris- $\mathrm{HCl}$ polyacrylamide gels for electrophoresis fractionation (Bio-Rad, Criterion). Proteins were transferred to a PVDF membrane, blocked with Odyssey blocking buffer (Li-Cor), and incubated overnight at $4^{\circ} \mathrm{C}$ with the following primary antibodies: rabbit $\mathrm{mAB}$ anti-FosB (1:500, Cell Signaling Technology catalog \#2251, RRID:AB_2106903) and mouse $\mathrm{mAB}$ anti-actin (1:20,000, Millipore catalog \#MAB1501, RRID:AB_2223041) in Odyssey blocking buffer. After thorough washing with $1 \times$ Tris-buffered saline plus $0.1 \%$ Tween $20(\mathrm{v} / \mathrm{v})$, membranes were incubated with IRDye secondary antibodies: donkey anti-rabbit IRDye 800 -conjugated antibody (1:5000 to 1:10,000, LI-COR Biosciences, catalog \#926-32213, RRID:AB_621848) and donkey anti-mouse IRDye 680conjugated antibody (LI-COR Biosciences catalog \#926-32222, RRID: AB_621844) diluted in Odyssey blocking buffer for $1 \mathrm{~h}$ at $22-25^{\circ} \mathrm{C}$. For analysis, the blots were imaged with the Odyssey Infrared Imaging system (Li-Cor) and quantified by densitometry using ImageJ. The amount of protein blotted onto each lane was normalized to levels of $\beta$-actin.

RNA extraction, $c D N A$ synthesis, and qPCR. We extracted total RNA from the tissue samples using TRIzol (Invitrogen) followed by homogenization and chloroform layer separation. We used the RNAeasy MicroKit (Qiagen) to process the clear supernatant layer and purify RNA as described by the manufacturer's instructions. After purification, RNA quality was analyzed with NanoDrop (Thermo Fisher Scientific). Then, $500 \mathrm{ng}$ of total RNA was then reverse transcribed to cDNA with qScript (Quanta Biosciences, 95048-500). The resulting cDNA was diluted to 1 ng $/ \mu$ l. For each qPCR, $3 \mu \mathrm{l}$ of cDNA was combined with $5 \mu$ l of Perfecta SYBR Green (Quanta Biosciences, 95054-02K), forward/reverse primers ( $1 \mu \mathrm{l}$ total), and $1 \mu \mathrm{l}$ of water. Samples were heated to $95^{\circ} \mathrm{C}$ for $2 \mathrm{~min}$ followed by 40 cycles of $95^{\circ} \mathrm{C}$ for $15 \mathrm{~s}, 60^{\circ} \mathrm{C}$ for $33 \mathrm{~s}$, and $72^{\circ} \mathrm{C}$ for $33 \mathrm{~s}$. Analysis was performed using the $\Delta \Delta \mathrm{C}(\mathrm{t})$ method. Samples were normalized to the GAPDH level. Primers used were as follows: Gapdh forward: (5'-AAC GGC ATT GTG GAA GG-3') and Gapdh reverse: (5' GGA TGC AGG GAT GAT GTT CT-3'), $\Delta$ FosB forward: (5'-AGG CAG AGC AGG AGT CGG AGA T- $3^{\prime}$ ) and $\Delta$ FosB reverse: (5'-GCC GAG TTG AAC TTC ACT CG-3').

Experimental design and statistical analysis. Experimental design for behavioral studies is based on the comparison of aggressive behavior in $\mathrm{RI}$ tests between the control and treatment groups (i.e., AAV- $\Delta$ FosB vs AAV-Ctrl). For the CPP test, AGG mice were randomly assigned to receive the control or $\triangle$ FosB-expressing viruses (either nonconditional AAV or Cre-dependent HSV vectors) and CPP scores were compared between the two groups using an unpaired Student's $t$ test. The number of animals per cohort is indicated in the text and figures. For cell-typespecific overexpression of $\Delta \mathrm{FosB}$, aggressive behavior was assessed for each animal through measurement of attack duration before and after receiving the $\Delta$ FosB-expressing or control virus. To compare the results between groups, we used the change in attack duration (attack duration after - attack duration before) for individual animals within each group. Comparison was made between the control and cell-type-specific $\Delta$ FosB-expressing groups using unpaired Student's $t$ tests. Histological analysis was performed on three sections of tissue and the results are reported as the average ratio of immunoreactive cells to the total MSN nuclei counted per high-power field $(40 \times$ oil objective) (Matamales et al., 2009). Data are presented as data points and bars indicate the mean \pm SEM. Numeric data in the text are presented as mean \pm SEM. We used GraphPad Prism 5.0 software (RRID:SCR_002798) to perform Student's $t$ tests to compare control and treatment groups. Correlations were tested by Pearson correlation coefficient (Pearson's $r$ ) using GraphPad Prism software. Statistical significance threshold was set a $p<0.05$ in all statistical tests. Degrees of freedom are indicated as $t$ (degree of freedom).

\section{Results \\ $\Delta$ FosB mRNA and protein expression are increased in the NAc of AGG mice}

Previously, we characterized individual differences in aggressive behavior among mature, sexually experienced CD-1 male mice and reported two distinct phenotypes: AGG and NON (Golden et al., 2016). To test whether aggressive behavior is associated with higher levels of $\Delta$ FosB, we quantified protein expression of $\Delta$ FosB in the NAc of AGG and NON CD-1 mice by Western blot $24 \mathrm{~h}$ after the last RI encounter of a $3 \mathrm{~d}$ screening (Fig. $1 A, B$ ). As demonstrated in Figure $1 C$ and $D$, the average level of $\Delta$ FosB protein in AGG was $\sim 50 \%$ higher than in NON (Fig. $1 D ; t_{(17)}=$ $2.829 ; p=0.0116$ ). There was a significant correlation between the average latency to initiate an attack over the course of $3 \mathrm{~d}$ screening and the level of $\Delta$ FosB (Fig. $1 E$, Pearson $r=-0.72, p=$ $0.03)$. Consistent with this increase in protein levels, $\Delta F o s B$ mRNA levels were increased by $\sim 80 \%$ in AGGs compared with NONs as determined by qPCR (Fig. $1 F ; t_{(18)}=2.692 ; p=0.0149$ ), with a similar correlation with average latency to initiate an attack (Fig. 1G, Pearson $r=-0.64, p=0.047$ ). The results of these experiments show a positive correlation between the level of $\Delta$ FosB in NAc and aggressive behavior in male mice.

\section{Overexpression of $\Delta$ FosB in NAc increases aggression and social dominance in AGGs}

The correlation between the level of $\Delta \mathrm{FosB}$ and aggression suggest that the induction of $\Delta$ FosB increases aggressive behavior in mice. To test this hypothesis, we first screened a cohort of CD-1 mice to identify mice of AGG phenotype and counterbalanced the experimental groups based on latency to initiate the first attack (Fig. $2 D$ ). We then virally induced global $\Delta$ FosB overexpression by injecting a nonconditional AAV2- $\Delta$ FosB-IRES-hrGFP (AAV- $\Delta$ FosB) vector into the NAc using AAV-YFP as a control. 
A

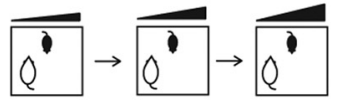

Physical

(3 Min.)

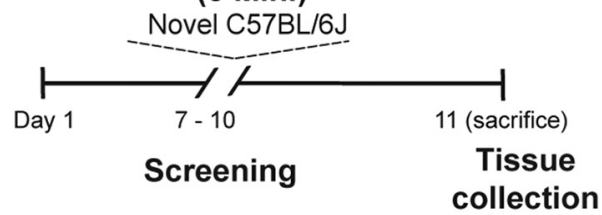

C

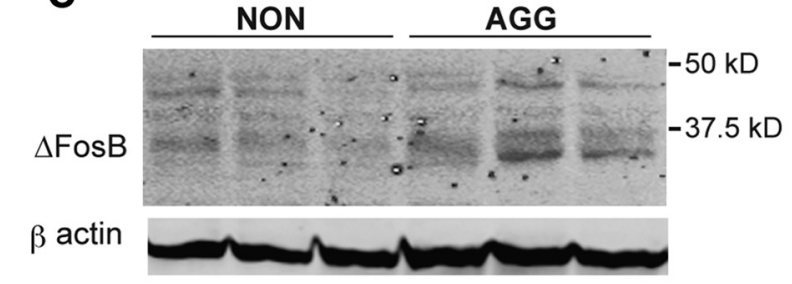

D

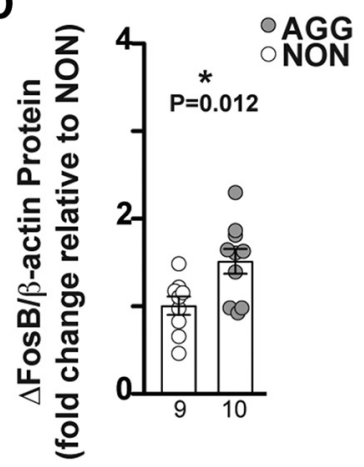

$\mathbf{F}$

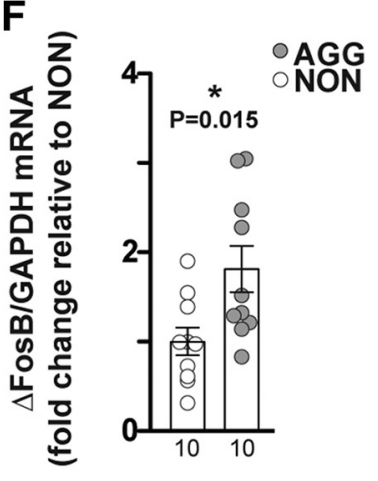

E

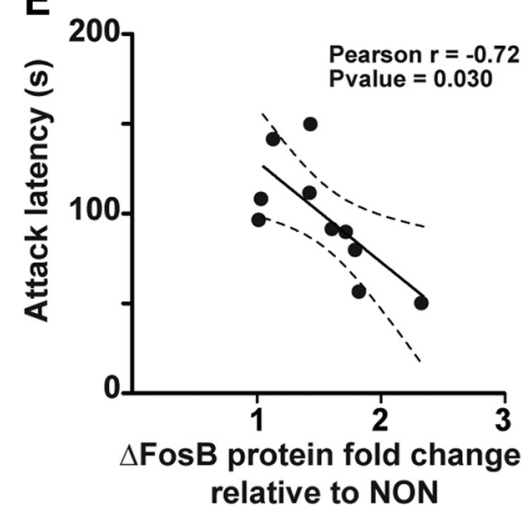

B

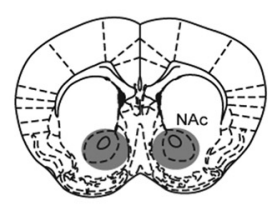

G

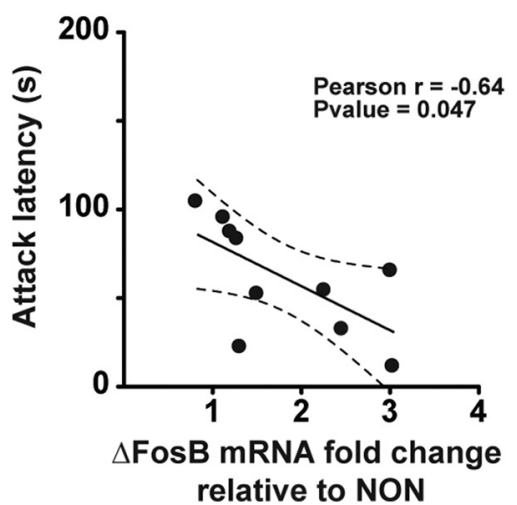

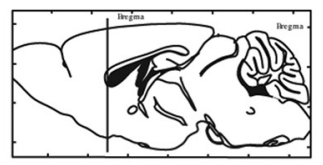

Figure 1. $\Delta$ FosB levels are increased in NAc of AGGs compared with NONs. $A$, Experimental timeline. $B$, Anatomical site of NAC tissue extraction. $C$, Representative Western blot: each lane is a protein extraction sample from one individual of NON or AGG phenotype. $\boldsymbol{D}$, Densitometry analysis of $35-37 \mathrm{kDa} \Delta$ FosB protein bands in AGGs $(n=10)$ and NONs $(n=9)$. All protein band densities are normalized to $\beta$-actin. $E$, Correlation of latency to initiate aggression (attack latency) and $\Delta$ FosB protein fold change relative to NONs. $\boldsymbol{F}$, qPCR analysis of NAc $\triangle$ FosB mRNA in AGGs $(n=10)$ compared with NONs $(n=10)$. $\boldsymbol{G}$, Correlation of attack latency with $\Delta$ Fos $B$ mRNA fold change relative to NONs. ${ }^{*} p<0.05$, unpaired, two-tailed Student's $t$ test.

We allowed 5 weeks for $\triangle \mathrm{FosB}$ to reach stable levels of expression before assessing aggression (Fig. $2 A$ ). We quantified aggressive behavior by performing a $3 \mathrm{~d}$ RI test (Fig. $2 E-H$ ). $\Delta$ FosBoverexpressing AGG mice showed significantly higher mean duration of aggression per bout (Fig. $2 H, t_{(18)}=3.132 ; p=0.0058$ ), indicating longer attack bouts. To rule out preexisting differ- ences between the groups, we scored the video recordings during the screening for attack duration $(\mathrm{GFP}=43.83 \pm 6.50 \mathrm{~s}$ and $\Delta \mathrm{FosB}=31.13 \pm 6.50 \mathrm{~s}, t_{(18)}=1.382$, $p=0.184)$ and attack duration per bout $(\mathrm{GFP}=12.05 \pm 2.23 \mathrm{~s}$, and $\Delta \mathrm{FosB}=$ $\left.9.37 \pm 1.66 \mathrm{~s}, t_{(18)}=0.964, p=0.348\right)$. These data indicate increased aggressive behavior in the $\Delta$ FosB-overexpressing group compared with controls. However, we were not able to convert NON mice to the AGG phenotype by overexpressing AAV- $\Delta$ FosB in NAc (Fig. $2 L-O$ ). The average time that mice spent on social exploration (nonaggressive) remained the same between the $\Delta$ FosB- and control-virusinjected groups, ruling out the possible effect of $\triangle \mathrm{FosB}$ overexpression on general nonagonistic social behavior of the AGG mice (Fig. $2 I, t_{(18)}=1.102, p=0.285$ ) or the NON mice (Fig. $2 P, t_{(14)}=1.021, p=$ 0.3246).

Establishing dominance by subjugating an opponent or winning a confrontation is one of the evolutionary advantages of aggressive behavior (Hiadlovská et al., 2015; Zhou et al., 2018). To assess directly whether overexpression of $\Delta \mathrm{FosB}$ increases dominance during social confrontation, we performed the tube test (Wang et al., 2011). AAV- $\Delta$ FosB-injected AGGs were paired with opponent AAV-GFP injected AGGs in a round robin design (Fig. $3 A$ ). AGGs injected with AAV- $\triangle$ FosB had a significantly higher victory rate than AGGs injected with AAV-GFP (Fig. 3B, $\left.t_{(25)}=5.672, p<0.0001\right)$, further indicating a positive role for $\Delta \mathrm{FosB}$ in dominance behavior. Average body weight was the same between the groups, ruling out the possible effect of $\Delta$ FosB overexpression on size as a confounding factor (Fig. $\left.3 C, t_{(37)}=0.3480, p=0.7298\right)$.

\section{Suppression of $\Delta$ FosB in the NAc attenuates aggression}

To test the necessity of $\Delta \mathrm{FosB}$ for aggressive behavior, we used a previously validated and published epigenome-editing strategy to suppress $\Delta$ FosB transcription in AGG mice by suppressing activity of the FosB promoter (Heller et al., 2014). HSVFosb-ZFP35-G9a and nonfunctional control (HSV-Fosb-ZFP35-NFD) viral vectors were injected into the NAc of AGG mice (Fig. $4 A-C)$. Analysis of aggression behavior (Fig. $4 F-I$ ) shows that suppression of $\Delta$ FosB expression attenuated aggressive behavior as indicated by a reduced number of attack bouts (Fig. $4 G, t_{(10)}=2.367, p=$ 0.0395 ), shorter attack duration (Fig. $4 H, t_{(8)}=2.913, p=$ 0.0195 ), and a trend of shorter attack duration per bout (Fig. $4 I$, $\left.t_{(8)}=2.241, p=0.0553\right)$. Suppression of $\Delta$ FosB expression did not affect social exploration (Fig. $4 J, t_{(13)}=1.24, p=0.2367$ ). 
A

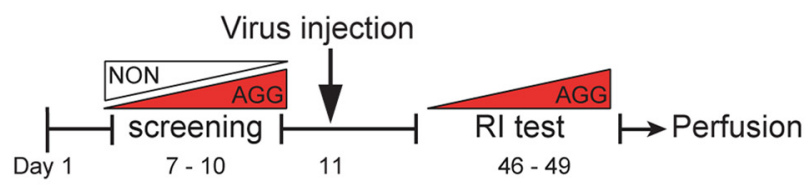

B

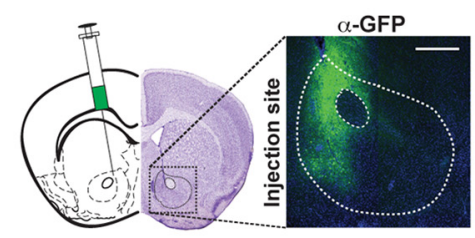

C

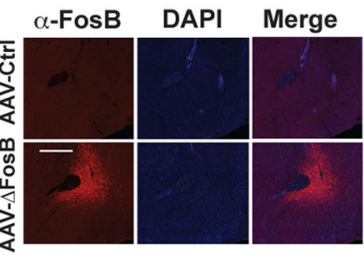

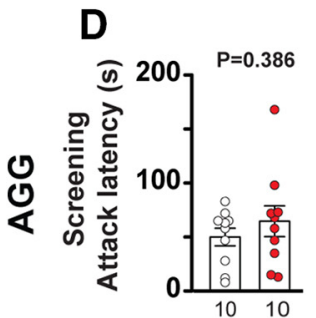

E

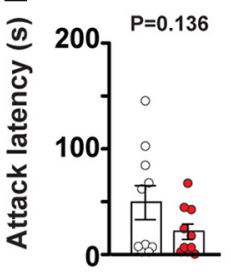

K
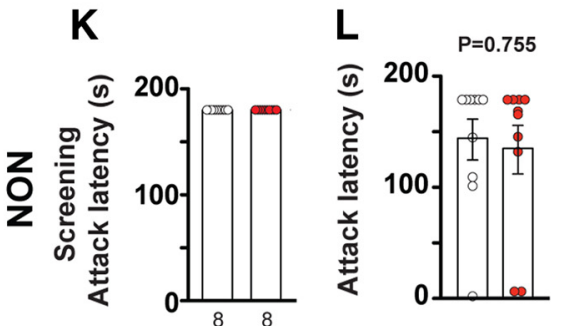
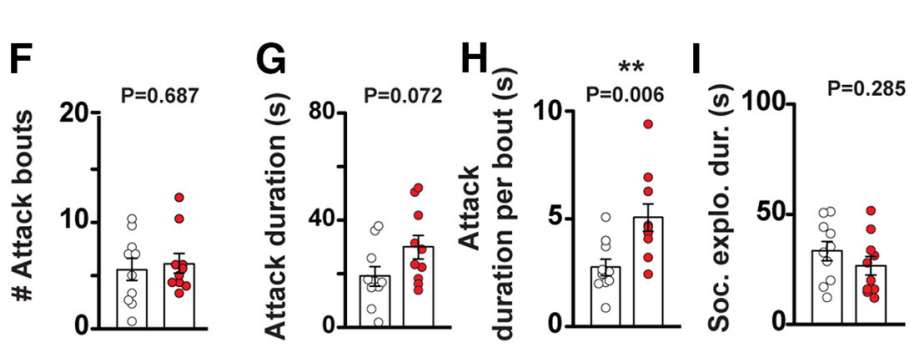

- AAV- $\triangle$ FosB OAAV-Ctrl
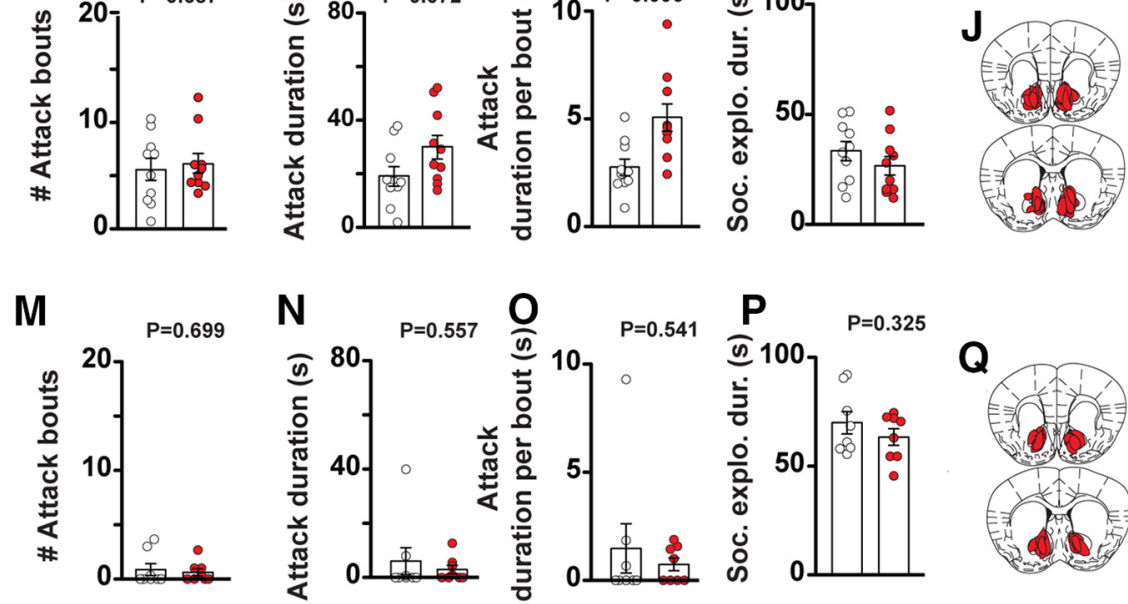

Figure 2. Overexpression of $\triangle F$ FosB in NAc increases the intensity of aggressive behavior only in aggressive mice. $\boldsymbol{A}$, Experimental timeline. $\boldsymbol{B}$, Anatomical site of virus injection in the NAc, inset represents the expression of YFP (control) in the NAc ( $\alpha$-GFP $=$ anti-GFP antibody). Scale bar, $500 \mu \mathrm{m}$. C, Immunofluorescent stained sections showing the expression of AAV- $\Delta$ FosB and the control virus $(\alpha$-FosB $=$ anti-FosB antibody). Scale bar, $500 \mu \mathrm{m}$. D, Latency to initiate aggression (attack latency) before virus injection in AGGs. $\boldsymbol{E}-\boldsymbol{H}$, Scoring of aggressive behavior in AGGs after injection with the control and $\triangle$ FosB-expressing virus ( $n=10$ mice per group). $I$, Social exploration duration between the AGG residents and intruders. $J$, Schematic representation of spread of viral expression of $\Delta$ FosB in front and back of the NAc in AGGs. $\boldsymbol{K}$, Latency to initiate aggression (attack latency) before viral injection in NONs (none of them attacked). $\boldsymbol{L}-\boldsymbol{0}$, Scoring of aggressive behavior in NONs after injection with the control and $\Delta$ FosB-expressing virus $(n=8$ mice per group). $\boldsymbol{P}$, Social exploration duration between the NON residents and intruders. $\boldsymbol{Q}$, Schematic representation of spread of viral expression of $\Delta$ FosB in anterior and posterior of the NAc in NONs. ${ }^{* *} p<0.01$, unpaired, two-tailed Student's $t$ test.
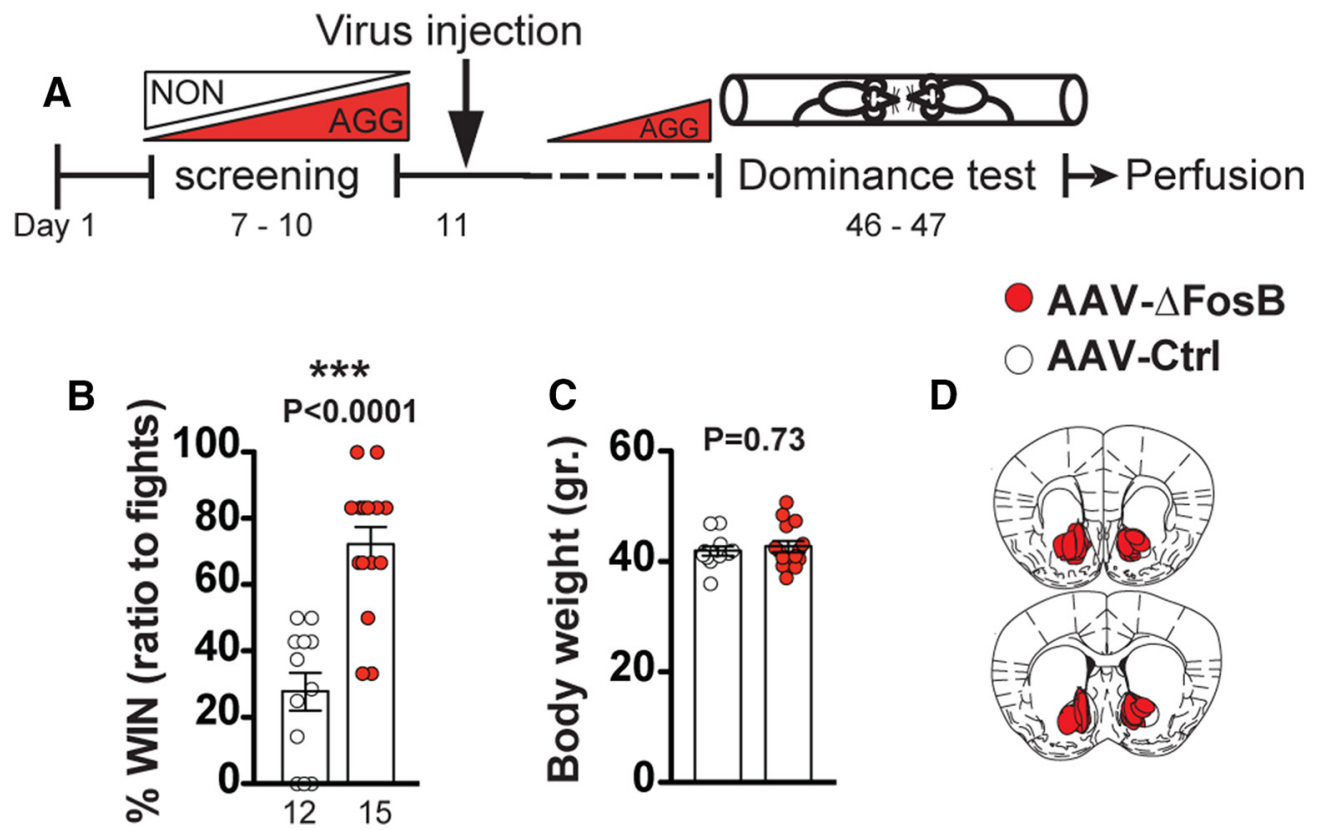

C

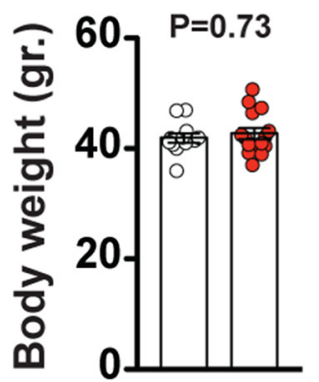

AAV- $\triangle$ FosB

AAV-Ctrl

D

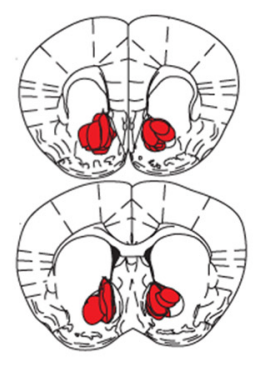

Figure 3. Overexpression of $\Delta$ FosB in NAc increases social dominance in AGG mice. $A$, Experimental timeline for tube test. $B, \Delta$ Fos $B$ overexpressing mice win a greater percentage of tube test trials against control animals. C, Comparison of the body weight in $\Delta$ FosB and control virus injected groups. $D$, Schematic representation of spread of viral of $\Delta$ Fos $B$ in anterior and posterior of the NAc. ${ }^{* * *} p<0.0001$, unpaired, two-tailed Student's $t$ test. 

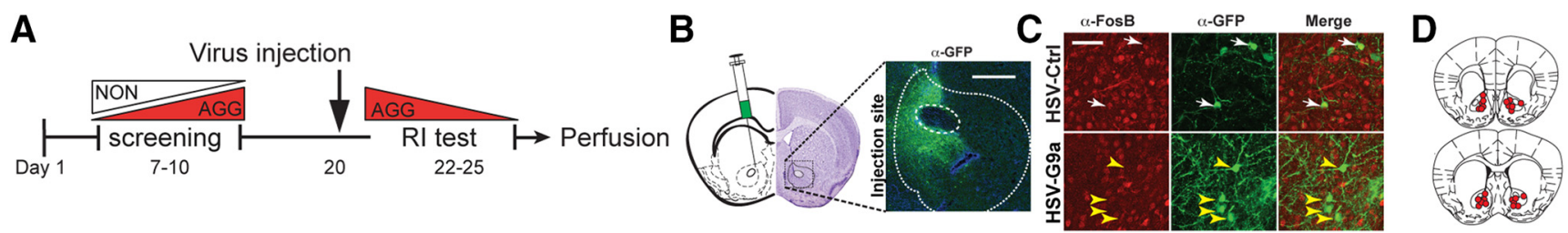

HSV-Fosb-ZFP-G9a

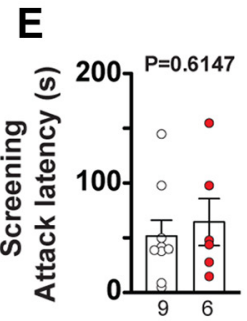

$\mathbf{F}$

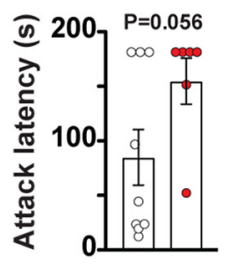

G

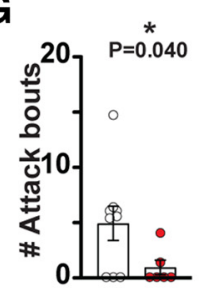

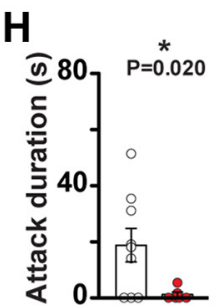

$J$

HSV-Fosb-ZFP-NFD
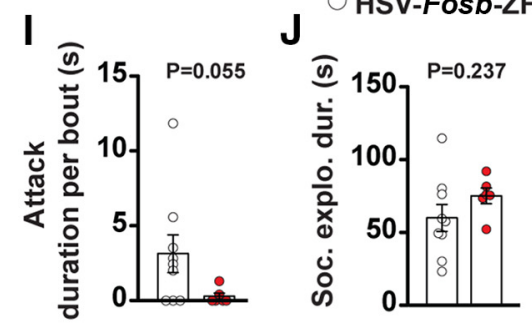

Figure 4. Suppression of the Fosb promoter in NAc attenuates aggression in mice. $A$, Experimental timeline. $\boldsymbol{B}$, Anatomical site of virus injection in the NAc and immunostaining indicating virus infected cells (GFP-labeled cells). Scale bar, $500 \mu \mathrm{m}$. C, HSV-Fosb-ZFP35-G9a (HSV-Fosb-ZFP-G9a) virus-infected NAccells show weaker or no FosB immunostaining (yellow arrowheads) compared with uninfected background cells. Control (HSV-Fosb-ZFP-NFD) virus-infected cells show levels of FosB immunostaining (white arrows) comparable to background cells. Scale bar, $50 \mu \mathrm{m}$. D, Schematic representation of viral placement and expression (HSV-Fosb-ZFP-G9a) in anterior and posterior sections of the NAc. $\boldsymbol{E}$, Latency to initiate aggression (attack latency) before virus injection. $\boldsymbol{F}$-I, Scoring of aggressive behavior after injection with control or HSV-Fosb-ZFP35-G9a-expressing virus ( $n=6$ for HSV-Fosb-ZFP35-G9a and $n=9$ for HSV- Fosb-ZFP35-NFD groups). $J$, Scoring of the social exploration duration of resident and intruder mice. ${ }^{*} p<0.05$, unpaired, two-tailed Student's $t$ test.

These results show that $\Delta \mathrm{FosB}$ in the NAc is necessary for the expression of intermale aggression.

\section{Cell-type-specific induction of $\Delta$ FosB in AGG mice}

To evaluate the cell-type-specific expression pattern of $\Delta$ FosB in aggressive behavior, we investigated the level of $\Delta \mathrm{FosB}$ in the two major MSN subpopulations of the NAc, D1-MSNs and D2-MSNs, after $3 \mathrm{~d}$ of RI testing in male mice (Fig. $5 A, B$ ). To distinguish between D1-MSNs and D2-MSNs, we used C57BL/6J transgenic mice that express a red fluorescent protein, td-Tomato, in D1-MSNs (D1tdTomato) (Fig. 5C). Analysis of confocal images showed that the FosB-immunoreactive cells were more numerous in the NAc of AGGs compared with NONs (Fig. $5 D, t_{(9)}=2.348, p=0.0435$ ) and $\mathrm{FosB}^{+}$-D1-MSNs were proportionally higher in D1-MSN population in AGGs compared with NONs (Fig. $5 E, t_{(9)}=2.511$, $p=0.0333)$. In contrast, the ratio of Fos ${ }^{+}-\mathrm{D} 1^{-}-\mathrm{MSNs}_{(\mathrm{FosB}}{ }^{+}{ }_{-}$ D2-MSNs) to the total number of D1 ${ }^{-}-\mathrm{MSN}$ (D2-MSNs) was not different between the AGGs and NONs (Fig. $5 F, t_{(9)}=1.330$, $p=0.2162$ ). Furthermore, when we included all 14 mice in the cohort, including the three mice that were inconsistent aggressors in our analysis, we observed a strong positive correlation between the ratio of $\mathrm{D}^{+}{ }^{+}-\mathrm{FosB}^{+}$MSNs to the total FosB ${ }^{+}$cells and several indices of aggressive behavior (Fig. $5 G-I$ ). The results of this experiment strongly indicate a cell-type-specific role for $\Delta$ FosB in NAc MSNs in aggressive behavior in male mice.

\section{Selective overexpression of $\Delta \mathrm{FosB}$ in D1-MSNs intensifies aggression}

To investigate the functional effect of cell-type-specific expression of $\Delta F$ osB on the intensity of aggressive behavior, we injected a previously validated and published cre-dependent $\Delta$ FosB expressing HSV viral vector (Grueter et al., 2013), HSV-LS1- $\Delta$ FosB, into the NAc of AGG D1-Cre or D2-Cre on C57BL/6J background mice $5 \mathrm{~d}$ after RI screening (Fig. 6A). Overexpression of $\triangle$ FosB in D1-MSNs increased aggression, as indicated by longer attack duration after the injection than before in the RI test compared with controls (Fig. $6 H, t_{(21)}=2.782, p=0.0112$ ). In contrast, overexpression of $\Delta$ FosB in D2-MSNs did not change aggressive behavior after injection compared with controls (Fig. $\left.6 \mathrm{~N}, t_{(16)}=0.8830, p=0.3903\right)$.

Cell-type-specific effects of $\Delta$ FosB in NAc on aggression CPP We next investigated whether induction of $\Delta$ FosB expression in the NAc increases aggression reward in the CPP test in AGG mice (Fig. 7A). Surprisingly, we found that overexpression of AAV$\Delta$ FosB in all neurons in the NAc attenuates the AGG preference for the intruder-paired side during CPP training (Fig. $7 B, t_{(18)}=$ $2.173, p=0.0434)$. These results indicate that, although overexpression of AAV- $\Delta$ FosB in all neurons in the NAc increases aggression, it does not promote aggression reward. This observation raises the possibility of a cell-type-specific role of $\Delta$ FosB in modulating rewarding aspects of aggression that is potentially masked when $A A V-\triangle F o s B$ is overexpressed in all neurons. To test this, we performed a CPP test on F1 CD-1-C57BL/6J hybrid D1-Cre and D2-Cre mice that received bilateral injections of HSV-LS1$\triangle$ FosB or control virus into the NAc (Fig. $7 C$ ). CPP results show that overexpression of $\triangle \mathrm{FosB}$ in D1-MSNs of the NAc did not change CPP in AGGs (Fig. $7 D, t_{(15)}=0.4121, p=0.6861$ ), whereas overexpression of $\triangle \mathrm{FosB}$ in the D2-MSNs induced an aversion to the intruder-paired chamber (Fig. $7 E, t_{(12)}=3.129$, $p=0.0087)$. Together, our data show that $\Delta$ FosB in D1-MSNs of AGG mice drives aggressive behavior without affecting the valence of the aggressive interaction, whereas $\Delta \mathrm{FosB}$ overexpression in D2 cells dampens the rewarding value of an aggressive encounter without affecting aggressive behavior.

\section{Discussion}

Aggression is an innate social behavior that serves an adaptive purpose in a competitive social structure. A growing number of studies show that repeated aggression with the opportunity of winning establishes aggression as a positive reward and reinforces continuation of the behavior (Fish et al., 2002, 2005; Fuxjager et al., 2010; Kudryavtseva et al., 2014; Falkner et al., 2016; Golden et al., 2016, 2017b). This form of escalated aggressive behavior shares some of the core features of addiction, including capacity for self-administration, high motivation to seek out aggression despite 


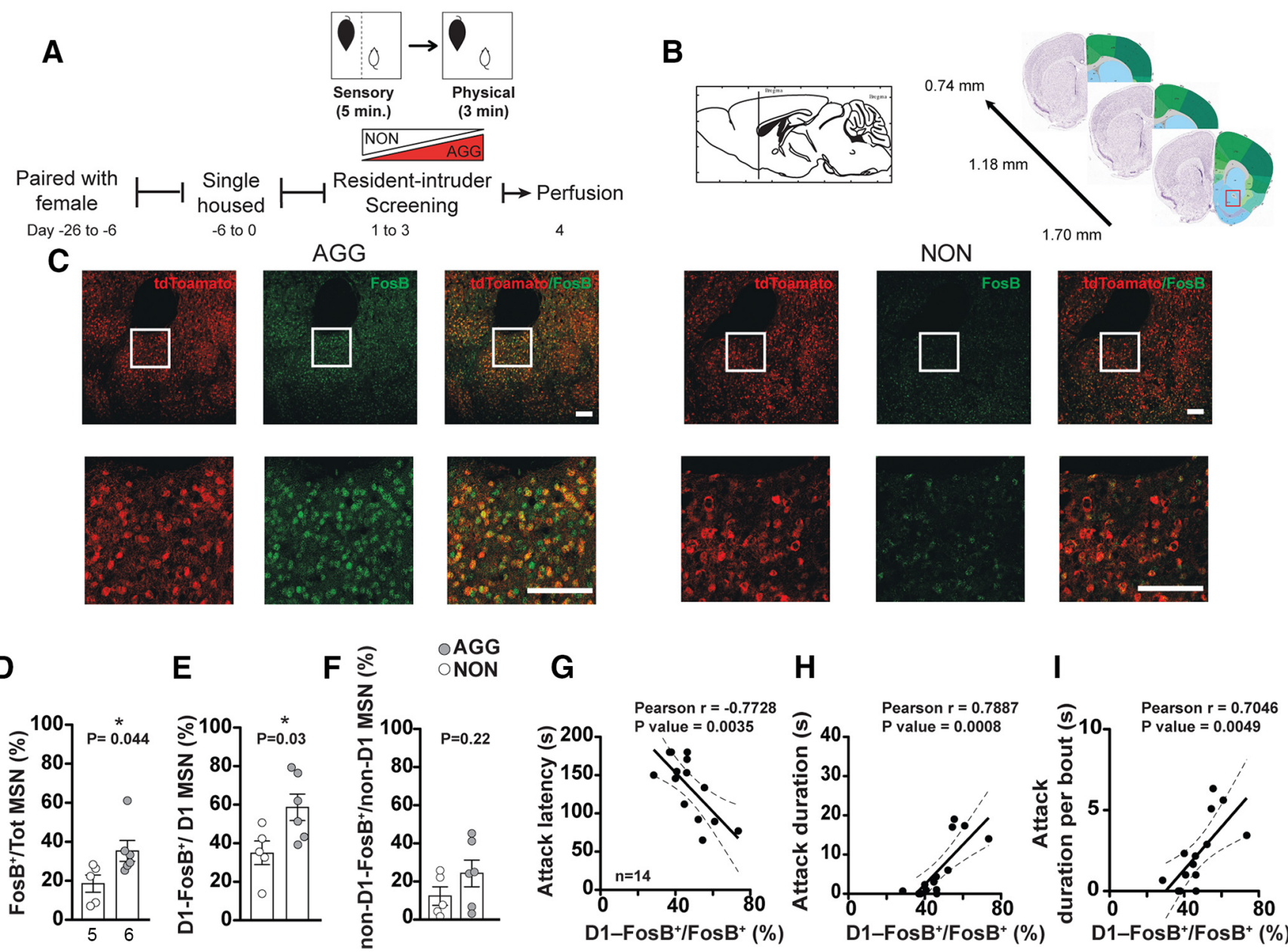

Figure 5. $\Delta$ FosB induction in D1-MSNs in the NAc after repeated aggression. $A$, Experimental timeline. $B$, Anatomical site of histological analysis. $\boldsymbol{C}$, Representative immunostained images of the NAc of D1-tdTomato mice in AGGs (left) and NONs (right). The area inside the square is magnified for detail. Scale bar, $100 \mu \mathrm{m}$. D, Ratio of total FosB + cells to total cell count (number of DAPI stained nuclei) $(40 \times)$ ( $n=5$ for NON, $n=6$ for AGG). $\boldsymbol{E}$, Ratio of FosB + cells colocalized with tdTomato (D1-MSN marker) to total number of D1-MSNs counted per high-power field. $F$, Ratio of FosB + cells that are not colocalized with tdTomato (non-D1 cells) to the total number of tdTomato-negative MSN nuclei counted per high-power field. G-I, Correlation of the ratio of D1 FosB ${ }^{+} / t_{0}$ otal FosB ${ }^{+}$ MSNs with aggressive behavior scores $(n=14) .{ }^{*} p<0.05$, unpaired, two-tailed Student's $t$ test.

possible adverse consequences, and relapse (Golden et al., 2017a). Ethological similarities between aggression and addiction demand the exploration of possible common molecular pathways that help us identify therapeutic targets to reduce aggressive behavior.

$\Delta \mathrm{FosB}$ is a transcription factor that promotes long-term changes in brain reward circuits after repeated exposure to virtually any drug of abuse or natural reward (e.g., food, sex, and exercise) and is a well established regulator of reward and reinforced behaviors. More recently, $\Delta$ FosB has been implicated in social behavior. For example, $\Delta$ FosB is reduced in the NAc of socially isolated mice and increased in animals that show resilience to chronic social stress (Vialou et al., 2010). In fact, overexpression of $\Delta$ FosB in NAc promotes social interaction and reduces anhedonia in stressed mice (Vialou et al., 2010; Donahue et al., 2014). Here, we demonstrate a direct correlation between the level of $\Delta F$ osB in the NAc after repeated fighting and the intensity of aggressive behavior. We also find that $\triangle \mathrm{FosB}$ in the NAc is necessary and sufficient for expression of aggressive behavior given that overexpression of $\Delta$ FosB intensifies aggressive behavior, whereas its suppression exerts the opposite effect. Surprisingly, nonconditional $\Delta$ FosB overexpression paradoxically decreases place conditioning for the aggression-paired context in the CPP test. Given this paradoxical decrease in aggression reward, we hypothesized that $\Delta$ FosB may be acting in a cell-type-specific fashion and that overexpression of the protein in all neurons masks any $\Delta$ FosB-mediated changes in aggression reward.

First, using D1-dtTomato reporter mice to distinguish the two primary neuronal types in NAc, we observed a cell-type-specific increase of $\Delta$ FosB in D1-MSNs with no change in D2-MSNs in response to repeated aggression. This finding resembles $\Delta$ FosB upregulation in D1-MSNs after repeated exposure to cocaine, a well established phenomenon (Kelz et al., 1999; Colby et al., 2003; Lobo et al., 2013; Chandra et al., 2015). Interestingly, cell-typespecific upregulation of $\triangle F$ FosB in D2-MSNs has been reported to be associated with opposing effects on social behavior. For example, Lobo et al. (2013) showed increased $\Delta$ FosB in D2-MSNs in mice that display depression-like syndrome with social avoidance in response to stress, whereas higher levels of $\Delta$ FosB in D1-MSNs is associated with a resilient phenotype. Recently, Hamilton et al. (2018) showed the sufficiency and necessity of FosB by cell-typespecific epigenetic regulation of this promoter activity in controlling social interaction in response to stress in D1-MSNs and D2-MSNs. In this study, the induction of Fosb promoter in D2MSNs increased social avoidance, whereas its suppression promoted a resilient phenotype in stressed mice. Functionally, we know from previous work that $\triangle$ FosB modulates D1-MSNs and 
A

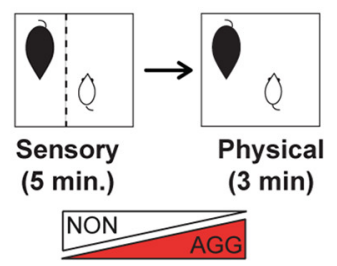

NoN

Day 1-3

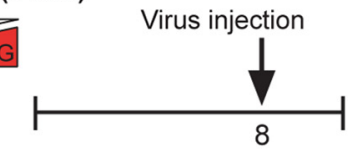

C

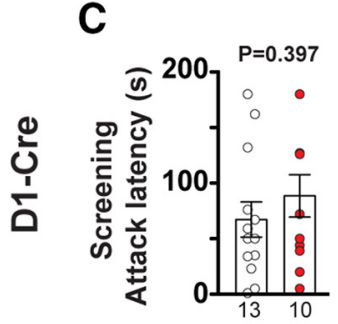

D

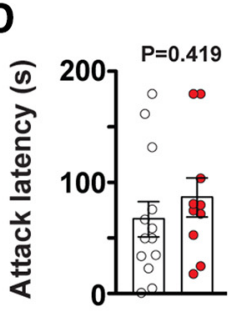

E
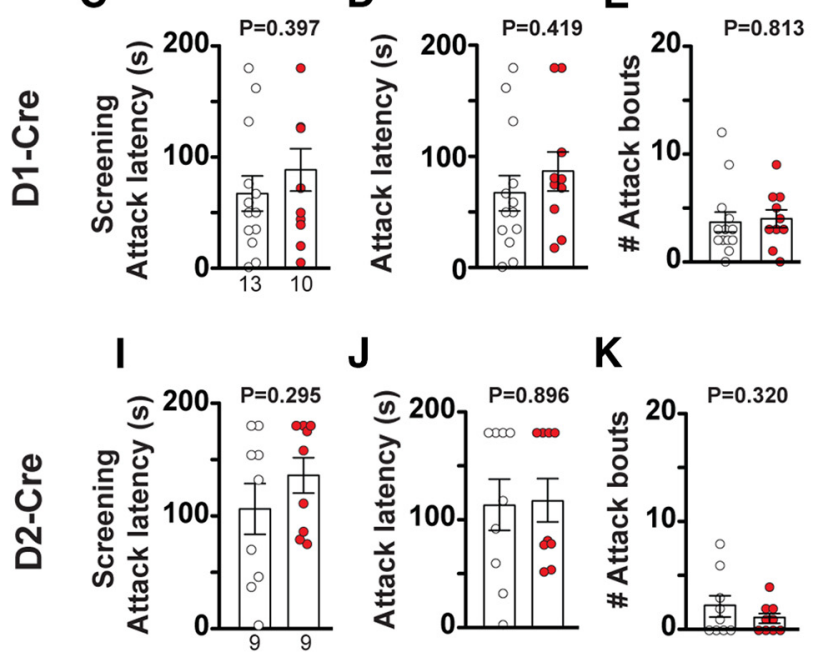

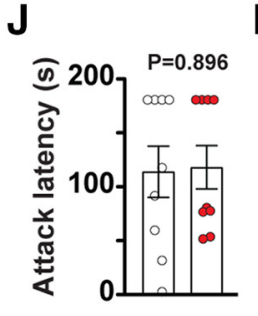

K

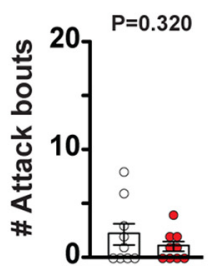

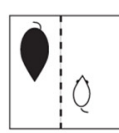

Sensory

(5 min.)

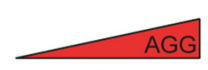

RI test

9-12

(a)

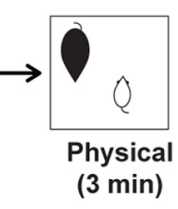

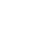

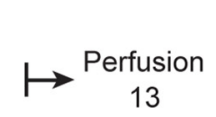
13
B

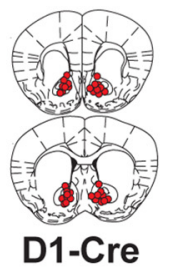

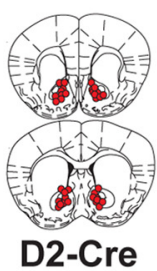

D2-Cre

\section{OHSV-CTRL oHSV-LS1- $\triangle$ FosB}
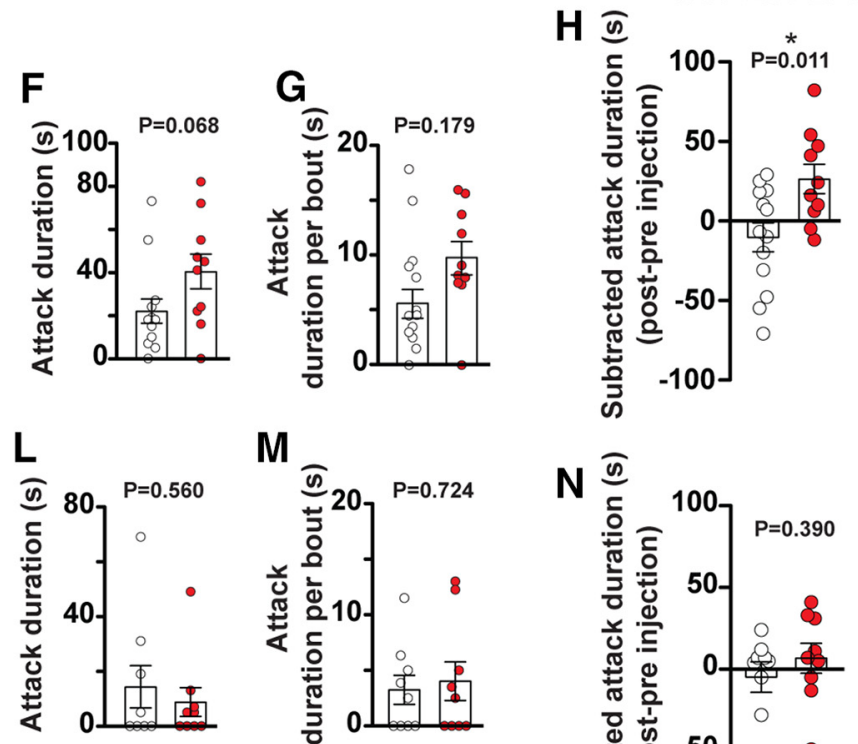

Figure 6. Cell-type-specific overexpression of $\Delta$ FosB in D1-MSNs, but not D2-MSNs, increases aggression intensity. $\boldsymbol{A}$, Experimental timeline. $\boldsymbol{B}$, Schematic representation of viral placement and expression (HSV-LS1- $\triangle$ Fos B) in anterior and posterior sections of the NAC. C, Latency to initiate aggression (attack latency) before virus injection in D1-Cre mice. D-G, Scoring of aggressive behavior in D1-Cre mice after injection with the control and cell-type-specific $\Delta$ FosB expressing virus ( $n=13$ for control, and $n=10$ for HSV-LS1- $\Delta$ FosB injected mice). $\boldsymbol{H}$, Subtracted attack duration before and after receiving cell-type-specific $\Delta$ FosB (HSV-LS1- $\Delta$ FosB) or GFP-expressing viruses in D1-Cre mice. I, Latency to initiate aggression (attack latency) before virus injection in D2-Cre mice. $\boldsymbol{J}-\boldsymbol{M}$, Scoring of aggressive behavior in D2-Cre mice after injection with the control and cell-type-specific $\Delta$ FosB expressing virus ( $n=9$ per group). $\boldsymbol{N}$, Subtracted attack duration before and after receiving cell-type-specific $\Delta$ FosB (HSV-LS1- $\Delta$ FosB) or GFP-expressing viruses in D2-Cre mice. ${ }^{*} p<0.05$, unpaired, two-tailed Student's $t$ test.

D2-MSNs differentially. For example, overexpression of $\Delta$ FosB in D1-MSNs in NAc decreases the AMPA/NMDA ratio, increases the number of immature spines, and increases CPP for cocaine. Conversely, overexpression of $\triangle \mathrm{FosB}$ in D2-MSNs increases the AMPA/NMDA ratio, but does not change immature spine numbers or CPP for cocaine (Grueter et al., 2013). Given the selective increase in $\triangle$ FosB in D1-MSNs after repeated aggression, we tested the functional role of cell-type-specific overexpression on both aggression and aggression reward. To gain cell-type-specific control on a CD-1 background, which was necessary because C57BL/6J mice are insufficiently aggressive for CPP studies, we generated F1 hybrids of CD-1 mice and transgenic C57BL/6J mice expressing Cre-recombinase in either D1-MSNs or D2-MSNs. As expected, overexpression of $\triangle$ FosB in D1-MSNs enhanced aggression, consistent with data obtained from overexpression in all NAc neurons. Surprisingly, overexpression of $\triangle$ FosB in D1MSNs had no effect on aggression reward, whereas $\Delta$ FosB overexpression in D2-MSNs promoted CPA. To our knowledge, this is the first example showing that $\Delta \mathrm{FosB}$ expression in D1-MSNs does not promote greater reward-related behavior to a rewarding stimulus. Collectively, our findings suggest that $\Delta$ FosB in D1MSNs is sufficient to regulate aggressive behavior without changing the valence for the aggressive social interaction. Our findings also provide unique insight into the functional consequences of $\Delta$ FosB overexpression in D2-MSNs because $\Delta$ FosB levels do not increase naturally in these neurons in response to aggression. Therefore, exogenous manipulation of increasing $\Delta$ Fosb in D2MSNs is highly suggestive of a novel therapeutic approach that might oppose the reward associated with aggression, a possibility that now requires direct investigation.

Despite the lack of effect of $\triangle$ FosB induction in D1-MSNs in NAc to promote aggression CPP, it is still possible that $\triangle$ FosB plays an important role in other motivational aspects of aggression. In this study, we used CPP to test and quantify the rewarding aspects of aggression. However, it will be important in future studies to investigate the role of $\Delta \mathrm{FosB}$ in modulating a range of other aggression-reinforced behaviors such as self-administration, extinction, and relapse (Golden et al., 2017a). These more complex procedures may indeed capture a role for $\Delta \mathrm{FosB}$ in the drive or motivation to engage in aggression.

Last, it is important to highlight the need for future translational studies on the molecular mechanisms of aggression. We currently have very few therapeutic options for the treatment of aggression and this is due at least in part to the fact that we know relatively little about the mechanisms driving it. It is critical to further explore downstream genes regulated by $\Delta \mathrm{FosB}$ and its 

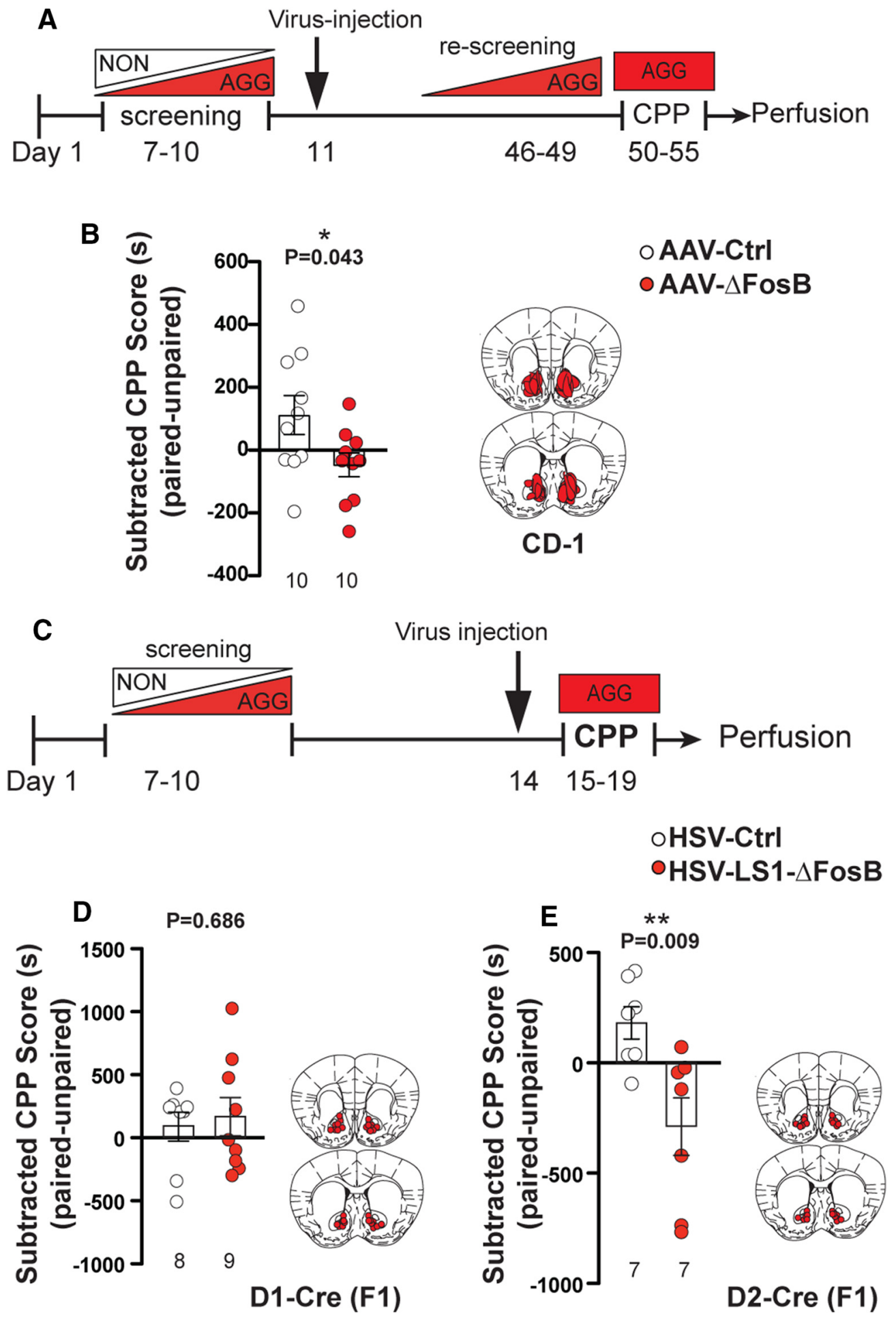

Figure 7. Overexpression of $\Delta$ FosB modulates aggression CPP differentially and in a cell-type-specific manner. $A$, Experimental timeline for CPP after non-cell-type-specific $\Delta$ FosB overexpression in the NAc. B, Left, CPP scores of AGG mice (CD-1) after receiving $\triangle$ FosB-expressing or control (YFP) AAV viral injections. Right, Schematic representation of spread of viral expression (AAV- $\triangle$ Fos B) in anterior and posterior sections of the NAc ( $n=10$ mice per group). C, Experimental timeline for CPP after cell-type-specific $\Delta$ FosB overexpression in the NAc. $D$, Left, CPP scores of D1-Cre $\times$ CD-1 (F1) AGG mice after receiving (re-dependent $\Delta$ FosB-expressing or control viral injections. Right, Schematic representation of viral placement and expression (HSV-LS1- $\Delta$ FosB) in anterior and posterior sections of the NAc ( $n=9$ for HSV-LS1- $\Delta$ FosB, and $n=8$ for control group). $E$, Left, CPP scores of D2-Cre $\times$ CD-1 (F1) AGG mice after receiving Cre-dependent $\Delta$ FosB expressing or control viral injections. Right, Schematic representation of viral placement and expression (HSV-LS1- $\Delta$ FosB) in anterior and posterior sections of the NAc ( $n=7$ mice per group). ${ }^{*} p<$ $0.05,{ }^{* *} p<0.01$, unpaired, two-tailed Student's $t$ test.

differential expression in D1-MSNs and D2-MSNs. However, previous studies have identified several $\Delta$ FosB-regulated genes that may be relevant to the behavioral effects of $\Delta$ FosB in aggression (McClung and Nestler, 2003). For example, calcium cal- modulin dependent protein kinase II (CaMKII) is one $\Delta$ FosB target gene that is upregulated in the NAc upon chronic cocaine and amphetamine administration and is important for synaptic changes and behavioral effects of these drugs (Loweth et al., 2010; 
Robison et al., 2013; Pizzo et al., 2014). It has also been shown to be important in mediating the antidepressant activity of fluoxetine in a mouse model of depression (Robison et al., 2014). CaMKII is a key modulator of AMPA receptor trafficking and synaptic transmission and plasticity (Herring and Nicoll, 2016). Considering that CaMKII is regulated differentially in D1-MSNs compared with D2MSNs in the NAc during chronic cocaine administration (Chandra et al., 2015), it is a highly relevant candidate for further investigation in aggression and aggression-seeking behavior models.

$\Delta$ FosB also directly regulates the expression of GluA2, a subunit of glutamate AMPA receptors that is required for behavioral adaptations in response to chronic cocaine use (Kelz et al., 1999). As Grueter et al. (2013) demonstrated, cell-type-specific overexpression of $\Delta$ FosB in in D1-MSNs and D2-MSNs in mouse NAc affects synaptic transmission in each of these cell populations. It specifically increases the AMPA/NMDA ratio in D2-MSNs in the NAc shell, whereas it decreases this ratio in D1-MSNs both in the NAc shell and core. This observation is particularly interesting because direct application of AMPA receptor antagonists reduced aggressive behavior in a selectively bred aggressive mouse line (Turku Aggressive; Vekovischeva et al., 2007).

Last, cholecystokinin (CCK) is another $\Delta$ FosB target gene that is expressed in the NAc that may drive the downstream effects of $\Delta$ FosB on aggression (McClung and Nestler, 2003). CCK has long been known as a modulator of motivational behaviors such as novelty exploration and drug-seeking behavior (Lu et al., 2002; Mitchell et al., 2006; Ballaz et al., 2008) and accumulating evidence indicates a possible role in aggressive behavior (Li et al., 2007; Katsouni et al., 2013; Nassel and Williams, 2014; Williams et al., 2014).

To develop treatments for aggression-targeting genes in D1MSNs and D2-MSNs, future studies should aim to determine the precise relationships among $\Delta$ FosB expression, its effects on target genes, and aggressive behavior. The results of such work could identify molecular targets beyond $\Delta$ FosB for developing new treatments for aggression. Another important finding of this study is that overexpression of $\Delta \mathrm{FosB}$ in D2-MSNs decouples aggression from the motivation to engage in aggressive behavior. This finding opens the possibility of developing therapeutic strategies that diminish the motivation for aggression in repeat offenders.

\section{References}

Ballaz SJ, Akil H, Watson SJ (2008) The CCK-system underpins noveltyseeking behavior in the rat: gene expression and pharmacological analyses. Neuropeptides 42:245-253. CrossRef Medline

Beiderbeck DI, Reber SO, Havasi A, Bredewold R, Veenema AH, Neumann ID (2012) High and abnormal forms of aggression in rats with extremes in trait anxiety-involvement of the dopamine system in the nucleus accumbens. Psychoneuroendocrinology 37:1969-1980. CrossRef Medline

Berton O, McClung CA, Dileone RJ, Krishnan V, Renthal W, Russo SJ, Graham D, Tsankova NM, Bolanos CA, Rios M, Monteggia LM, Self DW, Nestler EJ (2006) Essential role of BDNF in the mesolimbic dopamine pathway in social defeat stress. Science 311:864-868. CrossRef Medline

Carle TL, Ohnishi YN, Ohnishi YH, Alibhai IN, Wilkinson MB, Kumar A, Nestler EJ (2007) Proteasome-dependent and -independent mechanisms for FosB destabilization: identification of FosB degron domains and implications for DeltaFosB stability. Eur J Neurosci 25:3009-3019. CrossRef Medline

Chandra R, Francis TC, Konkalmatt P, Amgalan A, Gancarz AM, Dietz DM, Lobo MK (2015) Opposing role for Egr3 in nucleus accumbens cell subtypes in cocaine action. J Neurosci 35:7927-7937. CrossRef Medline

Christoffel DJ, Golden SA, Walsh JJ, Guise KG, Heshmati M, Friedman AK, Dey A, Smith M, Rebusi N, Pfau M, Ables JL, Aleyasin H, Khibnik LA, Hodes GE, Ben-Dor GA, Deisseroth K, Shapiro ML, Malenka RC, IbanezTallon I, Han MH, et al. (2015) Excitatory transmission at thalamo- striatal synapses mediates susceptibility to social stress. Nat Neurosci 18:962-964. CrossRef Medline

Colby CR, Whisler K, Steffen C, Nestler EJ, Self DW (2003) Striatal cell type-specific overexpression of DeltaFosB enhances incentive for cocaine. J Neurosci 23:2488-2493. CrossRef Medline

Couppis MH, Kennedy CH (2008) The rewarding effect of aggression is reduced by nucleus accumbens dopamine receptor antagonism in mice. Psychopharmacology 197:449-456. CrossRef Medline

Donahue RJ, Muschamp JW, Russo SJ, Nestler EJ, Carlezon WA Jr (2014) Effects of striatal DeltaFosB overexpression and ketamine on social defeat stress-induced anhedonia in mice. Biol Psychiatry 76:550-558. CrossRef Medline

Elbert T, Schauer M, Moran JK (2018) Two pedals drive the bi-cycle of violence: reactive and appetitive aggression. Curr Opin Psychol 19:135138. CrossRef Medline

Falkner AL, Grosenick L, Davidson TJ, Deisseroth K, Lin D (2016) Hypothalamic control of male aggression-seeking behavior. Nat Neurosci 19: 596-604. CrossRef Medline

Farrell WJ, Wilczynski W (2006) Aggressive experience alters place preference in green anole lizards, Anolis carolinensis. Animal Behaviour 71: 1155-1164. CrossRef

Fish EW, De Bold JF, Miczek KA (2002) Aggressive behavior as a reinforcer in mice: activation by allopregnanolone. Psychopharmacology 163:459_ 466. CrossRef Medline

Fish EW, DeBold JF, Miczek KA (2005) Escalated aggression as a reward: corticosterone and GABA(A) receptor positive modulators in mice. Psychopharmacology 182:116-127. CrossRef Medline

Fuxjager MJ, Forbes-Lorman RM, Coss DJ, Auger CJ, Auger AP, Marler CA (2010) Winning territorial disputes selectively enhances androgen sensitivity in neural pathways related to motivation and social aggression. Proc Natl Acad Sci U S A 107:12393-12398. CrossRef Medline

Golden SA, Covington HE 3rd, Berton O, Russo SJ (2011) A standardized protocol for repeated social defeat stress in mice. Nat Protoc 6:1183-1191. CrossRef Medline

Golden SA, Heshmati M, Flanigan M, Christoffel DJ, Guise K, Pfau ML, Aleyasin H, Menard C, Zhang H, Hodes GE, Bregman D, Khibnik L, Tai J, Rebusi N, Krawitz B, Chaudhury D, Walsh JJ, Han MH, Shapiro ML, Russo SJ (2016) Basal forebrain projections to the lateral habenula modulate aggression reward. Nature 534:688-692. CrossRef Medline

Golden SA, Heins C, Venniro M, Caprioli D, Zhang M, Epstein DH, Shaham Y (2017a) Compulsive addiction-like aggressive behavior in mice. Biol Psychiatry 82:239-248. CrossRef Medline

Golden SA, Aleyasin H, Heins R, Flanigan M, Heshmati M, Takahashi A, Russo SJ, Shaham Y (2017b) Persistent conditioned place preference to aggression experience in adult male sexually-experienced CD-1 mice. Genes Brain Behav 16:44-55. CrossRef Medline

Grueter BA, Robison AJ, Neve RL, Nestler EJ, Malenka RC (2013) FosB differentially modulates nucleus accumbens direct and indirect pathway function. Proc Natl Acad Sci U S A 110:1923-1928. CrossRef Medline

Hamilton PJ, Burek DJ, Lombroso SI, Neve RL, Robison AJ, Nestler EJ, Heller EA (2018) Cell-type-specific epigenetic editing at the fosb gene controls susceptibility to social defeat stress. Neuropsychopharmacology 43:272284. CrossRef Medline

Heller EA, Cates HM, Peña CJ, Sun H, Shao N, Feng J, Golden SA, Herman JP, Walsh JJ, Mazei-Robison M, Ferguson D, Knight S, Gerber MA, Nievera C, Han MH, Russo SJ, Tamminga CS, Neve RL, Shen L, Zhang HS, et al. (2014) Locus-specific epigenetic remodeling controls addiction- and depression-related behaviors. Nat Neurosci 17:1720-1727. CrossRef Medline

Herring BE, Nicoll RA (2016) Long-term potentiation: from CaMKII to AMPA receptor trafficking. Annu Rev Physiol 78:351-365. CrossRef Medline

Heshmati M, Aleyasin H, Menard C, Christoffel DJ, Flanigan ME, Pfau ML, Hodes GE, Lepack AE, Bicks LK, Takahashi A, Chandra R, Turecki G, Lobo MK, Maze I, Golden SA, Russo SJ (2018) Cell-type-specific role for nucleus accumbens neuroligin-2 in depression and stress susceptibility. Proc Natl Acad Sci U S A.

Hiadlovská Z, Mikula O, Macholán M, Hamplová P, Vošlajerová Bímová B, Daniszová K (2015) Shaking the myth: body mass, aggression, steroid hormones, and social dominance in wild house mouse. Gen Comp Endocrinol 223:16-26. CrossRef Medline

Katsouni E, Zarros A, Skandali N, Tsakiris S, Lappas D (2013) The role of cholecystokinin in the induction of aggressive behavior: a focus on the 
available experimental data (review). Acta Physiol Hung 100:361-377. CrossRef Medline

Kelz MB, Chen J, Carlezon WA Jr, Whisler K, Gilden L, Beckmann AM, Steffen C, Zhang YJ, Marotti L, Self DW, Tkatch T, Baranauskas G, Surmeier DJ, Neve RL, Duman RS, Picciotto MR, Nestler EJ (1999) Expression of the transcription factor deltaFosB in the brain controls sensitivity to cocaine. Nature 401:272-276. CrossRef Medline

Kudryavtseva NN, Bakshtanovskaya IV, Koryakina LA (1991) Social model of depression in mice of C57BL/6J strain. Pharmacol Biochem Behav 38:315-320. CrossRef Medline

Kudryavtseva NN, Smagin DA, Kovalenko IL, Vishnivetskaya GB (2014) Repeated positive fighting experience in male inbred mice. Nat Protoc 9:2705-2717. CrossRef Medline

Li Q, Deng X, Singh P (2007) Significant increase in the aggressive behavior of transgenic mice overexpressing peripheral progastrin peptides: associated changes in CCK2 and serotonin receptors in the CNS. Neuropsychopharmacology 32:1813-1821. CrossRef Medline

Lindenfors P, Tullberg BS (2011) Evolutionary aspects of aggression the importance of sexual selection. Adv Genet 75:7-22. CrossRef Medline

Lobo MK, Zaman S, Damez-Werno DM, Koo JW, Bagot RC, DiNieri JA, Nugent A, Finkel E, Chaudhury D, Chandra R, Riberio E, Rabkin J, Mouzon E, Cachope R, Cheer JF, Han MH, Dietz DM, Self DW, Hurd YL, Vialou V, Nestler EJ (2013) DeltaFosB induction in striatal medium spiny neuron subtypes in response to chronic pharmacological, emotional, and optogenetic stimuli. J Neurosci 33:18381-18395. CrossRef Medline

Loweth JA, Singer BF, Baker LK, Wilke G, Inamine H, Bubula N, Alexander JK, Carlezon WA Jr, Neve RL, Vezina P (2010) Transient overexpression of alpha-Ca2+/calmodulin-dependent protein kinase II in the nucleus accumbens shell enhances behavioral responding to amphetamine. J Neurosci 30:939-949. CrossRef Medline

Lu L, Zhang B, Liu Z, Zhang Z (2002) Reactivation of cocaine conditioned place preference induced by stress is reversed by cholecystokinin-B receptors antagonist in rats. Brain Res 954:132-140. CrossRef Medline

Martínez M, Guillén-Salazar F, Salvador A, Simón VM (1995) Successful intermale aggression and conditioned place preference in mice. Physiol Behav 58:323-328. CrossRef Medline

Matamales M, Bertran-Gonzalez J, Salomon L, Degos B, Deniau JM, Valjent E, Hervé D, Girault JA (2009) Striatal medium-sized spiny neurons: identification by nuclear staining and study of neuronal subpopulations in BAC transgenic mice. PLoS One 4:e4770. CrossRef Medline

McClung CA, Nestler EJ (2003) Regulation of gene expression and cocaine reward by CREB and DeltaFosB. Nat Neurosci 6:1208-1215. CrossRef Medline

Meisel RL, Joppa MA (1994) Conditioned place preference in female hamsters following aggressive or sexual encounters. Physiol Behav 56:11151118. CrossRef Medline

Miczek KA, O’Donnell JM (1978) Intruder-evoked aggression in isolated and nonisolated mice: effects of psychomotor stimulants and L-dopa. Psychopharmacology 57:47-55. CrossRef Medline

Mitchell JM, Bergren LJ, Chen KS, Fields HL (2006) Cholecystokinin is necessary for the expression of morphine conditioned place preference. Pharmacol Biochem Behav 85:787-795. CrossRef Medline

Nassel DR, Williams MJ (2014) Cholecystokinin-like peptide (DSK) in Drosophila, not only for satiety signaling. Front Endocrinol (Lausanne) 5:219. CrossRef Medline
Nehrenberg DL, Sheikh A, Ghashghaei HT (2013) Identification of neuronal loci involved with displays of affective aggression in NC900 mice. Brain Struct Funct 218:1033-1049. CrossRef Medline

Nestler EJ (2012) Transcriptional mechanisms of drug addiction. Clin Psychopharmacol Neurosci 10:136-143. CrossRef Medline

Nestler EJ (2015) FosB: a transcriptional regulator of stress and antidepressant responses. Eur J Pharmacol 753:66-72. CrossRef Medline

Neve RL, Neve KA, Nestler EJ, Carlezon WA Jr (2005) Use of herpes virus amplicon vectors to study brain disorders. Biotechniques 39:381-391. CrossRef Medline

Olausson P, Jentsch JD, Tronson N, Neve RL, Nestler EJ, Taylor JR (2006) DeltaFosB in the nucleus accumbens regulates food-reinforced instrumental behavior and motivation. J Neurosci 26:9196-9204. CrossRef Medline

Pizzo AB, Karam CS, Zhang Y, Ma CL, McCabe BD, Javitch JA (2014) Amphetamine-induced behavior requires CaMKII-dependent dopamine transporter phosphorylation. Mol Psychiatry 19:279-281. CrossRef Medline

Robison AJ, Nestler EJ (2011) Transcriptional and epigenetic mechanisms of addiction. Nat Rev Neurosci 12:623-637. CrossRef Medline

Robison AJ, Vialou V, Mazei-Robison M, Feng J, Kourrich S, Collins M, Wee S, Koob G, Turecki G, Neve R, Thomas M, Nestler EJ (2013) Behavioral and structural responses to chronic cocaine require a feedforward loop involving DeltaFosB and calcium/calmodulin-dependent protein kinase II in the nucleus accumbens shell. J Neurosci 33:4295-4307. CrossRef Medline

Robison AJ, Vialou V, Sun HS, Labonte B, Golden SA, Dias C, Turecki G, Tamminga C, Russo S, Mazei-Robison M, Nestler EJ (2014) Fluoxetine epigenetically alters the CaMKIIalpha promoter in nucleus accumbens to regulate DeltaFosB binding and antidepressant effects. Neuropsychopharmacology 39:1178-1186. CrossRef Medline

Vekovischeva OY, Aitta-aho T, Verbitskaya E, Sandnabba K, Korpi ER (2007) Acute effects of AMPA-type glutamate receptor antagonists on intermale social behavior in two mouse lines bidirectionally selected for offensive aggression. Pharmacol Biochem Behav 87:241-249. CrossRef Medline

Vialou V, Robison AJ, Laplant QC, Covington HE 3rd, Dietz DM, Ohnishi YN, Mouzon E, Rush AJ 3rd, Watts EL, Wallace DL, Iñiguez SD, Ohnishi YH, Steiner MA, Warren BL, Krishnan V, Bolaños CA, Neve RL, Ghose S, Berton O, Tamminga CA, et al. (2010) DeltaFosB in brain reward circuits mediates resilience to stress and antidepressant responses. Nat Neurosci 13:745-752. CrossRef Medline

Wallace DL, Vialou V, Rios L, Carle-Florence TL, Chakravarty S, Kumar A, Graham DL, Green TA, Kirk A, Iñiguez SD, Perrotti LI, Barrot M, DiLeone RJ, Nestler EJ, Bolaños-Guzmán CA (2008) The influence of DeltaFosB in the nucleus accumbens on natural reward-related behavior. J Neurosci 28:10272-10277. CrossRef Medline

Wang F, Zhu J, Zhu H, Zhang Q, Lin Z, Hu H (2011) Bidirectional control of social hierarchy by synaptic efficacy in medial prefrontal cortex. Science 334:693-697. CrossRef Medline

Williams MJ, Goergen P, Rajendran J, Klockars A, Kasagiannis A, Fredriksson R, Schiöth HB (2014) Regulation of aggression by obesity-linked genes TfAP-2 and twz through octopamine signaling in Drosophila. Genetics 196:349-362. CrossRef Medline

Zhou T, Sandi C, Hu H (2018) Advances in understanding neural mechanisms of social dominance. Curr Opin Neurobiol 49:99-107. CrossRef Medline 